\title{
III Complex Continuities
}

The case for simple continuities of pre-evolutionary thinking in the works of such authors as Galton, Kretschmer, and Sheldon is easily made-so easily that many critics of contemporary biological determinism dismiss important contemporary authors with a polemical but perhaps too derisive wave of the hand. The Sociobiology Study Group, for example, dismisses E. O. Wilson's statements about humans in an article titled "Sociobiology-New Biological Determinism" (I977).

Such an approach will not win the day. There are indeed continuities between pre-evolutionary and contemporary biological determinist views of humans, but the issue is not therefore simple. A number of contemporary thinkers have made good-faith efforts to treat humans in accordance with what they conceive to be the requirements of an evolutionary perspective, only to continue key elements of preand nonevolutionary thought against their own intentions. This complex kind of continuity can be seen in E. O. Wilson's human sociobiology and Marvin Harris' cultural materialism, among many other contemporary biologically based approaches. 
Two mistakes are often made in attacking such efforts. The most common is to assume that these scholars are acting in bad faith, that they are nefarious conspirators against the truth. The reduction of scientific controversy to a battle between the good guys and the bad guys is a strategy usually employed when intellectually based criticism seems too weak for the task. To assume that such thinkers are operating in bad faith is both intellectually sterile and overoptimistic. More frightening to contemplate is the possibility that intelligent, sincere, well-trained scientists can expend their efforts on these problems and then unknowingly reproduce quite predictable pre- and nonevolutionary views. This possibility suggests that a powerful and durable cultural system, rather than some personal failure of rationality and good faith, lies at the center of the problem.

Equally important is the consistent failure to set contemporary thinkers in an adequate intellectual/historical context. ${ }^{1}$ Were I now to discuss Wilson and Harris directly against the backdrop of Hippocrates, Jean Bodin, and Francis Galton, I would be treating them stereotypically. Their arguments are detailed, complex, and keyed to a restricted range of biological and evolutionary issues-the evolution of social forms for Wilson and the relation between social practices and ecological adaptation for Harris. To treat them as if they were global biological determinists is to miss the subtlety of their arguments. Such an approach also fails to account for the attractiveness of their arguments to many academic audiences, unless we believe that these audiences also share social class interests with the authors.

To cope with these problems, it is necessary to pose such contemporary thinkers as Wilson and Harris against analyses of some of their legitimate pre-evolutionary counterparts. A fair comparison is one in which the specific subject and the level of detail of the preevolutionary view are on a par with those of the contemporary author's effort. For this reason, Chapters 4 and 5 demonstrate in detail how humoral/environmental theories have been deployed socially to explain and legitimate particular social arrangements. ${ }^{2}$ In the first case, they are used to support a hierarchical system through a strong emphasis on genealogical arguments; in the second, a more egalitarian system is supported by a view that centers, in part, on assertions about the requirements of successful accommodation to the environment. 
In these detailed contexts, which elaborate considerably the arguments I have already made about humoral/environmental theories, I set the works of E. O. Wilson (Chapter 6) and Marvin Harris (Chapter 7). 



\section{CHAPTER 4}

\section{Purity of Blood and Social Hierarchy}

Humoral/environmental theories have generated highly specific and elaborate rationales and explanations of particular political systems, both hierarchical and egalitarian. Indeed, much of their appeal arises from their promise to correlate detailed and specific "natural laws" with particular social structures.

The ideological system that supported and explained the separation of nobles and commoners throughout the Middle Ages and the Renaissance rested on humoral/environmental theories, with their reliance on fixed "natural" categories. European concepts of nobility were based on the assertion that nobles enjoyed superior social status because of the material quality (purity) of their blood; that is, the social hierarchy expressed a natural hierarchy in the quality of the humors of the populace. These ideas, far from being rigid, could be employed to explain and justify very different kinds of hierarchical social structures. There is a tendency to treat the past in unidimensional fashion. Part of the staying power of humoral/environmental theories arises from their immense flexibility.

Blood has received an extraordinary amount of attention in West- 
ern thought. Blood as the primary source of the other humors, blood as life, blood as death, bleeding of patients, menstrual blood, the blood of religious sacrifice, and the blood of kinship encompass a vast field of Western discourse. We can get a glimpse of these riches in the widespread notion of the pure blood of nobility.

\section{Classical Ideas about Blood and Behavior}

Beyond the four-part humoral view already discussed, certain classical ideas about body fluids form a backdrop for the concept of blood nobility. ${ }^{1}$ In Greek thought, the lungs (viewed as blackish, spongy sacks containing blood and breath) were the seat of consciousness. The various states of consciousness were attributed to degrees and types of moisture in the lungs. Dry lungs yielded the alertness and sobriety characteristic of the waking state. Wet lungs, characteristic of the sleeping state, resulted in loss of awareness and forgetfulness. The drinking of wine could cause the lungs to be wet.

The interaction between blood and breath was the very stuff of consciousness. When air was drawn into the lungs, it interacted there with blood, which gave off its vapors (consciousness and intelligence) in the breath. "Greeks and Romans related consciousness and intelligence to the native juice in the chest, blood (foreign liquids affected consciousness for the most part adversely), and to the vapour exhaled from it, breath" (Onians [x95x] 1973:63).

The head-perhaps more accurately the brain and its fluids-was revered as the seat of the seeds of being and individual character. The head was the essence of a person in a genealogical sense. In the Greek view, the head was connected through the spine to the genitals, the two linked by another liquid, the cerebrospinal fluid, called aiōn. Together these fluids, blood and cerebrospinal fluid, gave rise to the states of consciousness and essential character of individual human beings. Both aion and blood were passed on generationally and both were affected by the environment. Thus both were part of the "natural frame."

The complexity of the distinction between the cerebrospinal fluid and blood gave rise to an extensive medical literature. Learned de- 
bates raged about the source of the cerebrospinal fluid and its functions - was it a fifth humor, a product of the blood, or a direct product of digestion? ${ }^{2}$

Regardless of the conceptualization of the relationship between blood and cerebrospinal fluid, there was general agreement that the material states of these fluids directly influenced behavior. The genealogical principles gave an individual a particular constitutional makeup of blood and aion, and the environmental principle continuously acted on that "natural frame," causing modifications in their states.

In explanations of nobility, the main emphasis was on the primacy of the genealogical principle in the creation of noble behavior. One could be noble by genealogy only. To admit environmental influences on nobility would be to imperil the exclusionary system. Yet humoral theories are by no means intrinsically nonegalitarian, as the discussion of Enlightenment uses of humoral doctrines in Chapter 5 will show.

Concepts of Nobility and Blood in Spain

The wealth of Spanish documentation on the subject of blood nobility is awesome, and the diversity of motivations of the writers adds a fascinating complexity to the subject. Classical authors, churchmen, monarchs and their jurists, and jurists representing other interests were all involved.

\section{The Classes of Nobility}

The most widely accepted classifications of types of nobility appearing in Spanish documents from the fourteenth century onward were the product of syntheses developed by Spanish jurists who read the classical and ecclesiastical texts on this subject and then disputed each other in print. According to these authors, there were three classes of nobility. The first, primary natural nobility (nobleza natural primera), included all classes of entities, animate and inanimate. Because God created all the categories, they all had intrinsic dignity and importance. Each species of entity contained better and worse repre- 
sentatives. The best representatives were called "noble." The connection between this idea and the chain of being is clear. What is noble in the natural world is that which most closely approximates the eternal Idea of it. This first category of nobility formed a background for all viewpoints and was not actively disputed.

The second class of nobility, natural secondary and moral nobility (nobleza natural secundaria y moral), was unique to human beings. It came to individuals either through direct inheritance from the first fathers of humanity or because, through great acts of valor or wisdom, the individuals had restored their bloodlines to the purity characteristic of the first fathers. This class of nobility was also called nobility of blood (hidalguia de sangre).

Humans were initially created by God in a state of purity. In this original state, all human actions were right actions, for nothing could have caused them to be otherwise. But humans were also created with the ability to sin, and through sin they fell from this original state of purity. Those humans whose behavior most closely approximated that of the first fathers of humanity and who, through all generations, maintained a steadfast commitment to right actions and reverence to God were considered to be noble: "Nobility is nobility that comes to man by lineage" (Alfonso X [El Sabio] [c. 1265] I 848).

In this view, nobility was the closest approximation to the original purity of creation, and it was transmitted genealogically. Those who through sin, heresy, or disloyalty stained their bloodlines were no longer noble. Such people were, of course, the immense majority.

There were two categories of people who could claim nobility of blood. The first consisted of the magnates, those extremely famous and wealthy Spanish families whose background and nobility could not be questioned because of their social power. The behavior and social prominence of another lesser group suggested that they, too, were noble, though they did not have the power and wealth to force public recognition. These people petitioned the ruler for letters patent of nobility (executorias). In theory, the ruler could neither absolve people of their sins nor purify their lineages; but as God's lieutenant on earth, he had the power to examine the records of a person's behavior and family background. If these records indicated that the person was truly noble, the ruler could grant the letters patent that "rec- 
ognized" (not created or granted) that nobility. Nobles who gained their status in this manner were called nobles by letters patent (hidalgos de executoria) but were also considered to be nobles by blood (bidalgos de sangre).

The third class of nobility was civil political nobility (nobleza politica civil). This kind of nobility was granted to individuals by a ruler in recognition of their service to the crown. It was a prize of honor awarded by the state to its servants because of their superiority in the use of the sword or the pen. Such people were also called nobles by grant (hidalgos de privilegio). There were numerous categories of grant (Isasti [I625, I850] I972, Moreno de Vargas [1636] 1795, Nueva recopilación... [1696] I918).

Thus there were three major roads to socially recognized nobility: proper genealogy combined with general public recognition of it, proper genealogy and right actions recognized as such by a ruler, and service to a ruler sufficient to merit a grant of nobility. In theory, all three rested on the same basic principle: the genealogical transmission of material purity of blood that caused right action and belief. The purity/nobility relationship was the core of this naturalistic explanation and justification of human behavior and hierarchical social structures.

\section{Double Meanings}

A key to the operation of this system of concepts was the multiple meaning of biological/physical terms. Blood was a physical substance circulating through the body and, following the humoral theory, was a direct cause of an individual's character and actions. Certain qualities of blood were important in the concept of nobility: purity, clarity, and cleanliness. It was not blood itself that made right actions, but its purity, clarity, and cleanliness. Purity of blood was not conceived as a metaphor in any sense; it was felt to be a specific physical property. Purity of blood resulted from genealogy and consanguinity.

The antitheses of these concepts helped to bound this conceptual universe and set its social context. The opposite of nobleman was commoner, and the opposite of the nobility was the populace. The quality opposed to purity/clarity/cleanliness was impurity or (the term 


\section{II2 | Complex Continuities}

most commonly used at the time) mixture. The opposite of nobility was thus mixture, meaning both physical mixture of noble and nonnoble blood (creating impurity) and the social mixture arising from unknown genealogical background (always assumed to mean mixed noble and commoner elements). By the same logic, the state of purity had to be proved, for purity was the exception. The ordinary human condition was mixture.

A number of ambiguities must be dealt with at this point. First, as we have seen, there are two Spanish terms that we translate as "nobility" in English: nobleza and hidalguia. My understanding is that bidalguia came into use later and that the term emphasizes the social implications of nobility. The derivations of these terms supplied by jurists of the period are highly fanciful.

Ambiguities in the meanings of blood do not end with nobility, since ideas about blood expand into the realm of fertility, racial differences, and so on. There were also complex debates about the nobility of women, especially when a noblewoman married a commoner or a commoner woman married a nobleman.

\section{Principles and Social Realities}

A much deeper ambiguity centers on the sources of nobility themselves. In the ideal model, nobility was a direct genealogical transmission from the first fathers of humanity, who were created pure in blood. By this genealogical principle, anyone who was noble had to be directly descended from them. Yet the theoretical systems also recognized the possibility that people could, through right acts, restore purity to their bloodlines. This view is much harder to rationalize theoretically within the genealogical principle. After all, if purity of blood directly caused noble behavior, how was it possible for someone with impure blood to act in such a way as to purify it? The diffculty is great and its logic is readily understood. The legitimacy of noble privilege was given a naturalistic justification in a genealogy that supposedly placed it beyond the reach of most people. After all, a privilege that anyone could receive would be no privilege at all. Thus the whole idea of nobility was tied to the genealogical principle. 
Yet a social system that could not accommodate social mobility could not survive. The active and often wealthy servants of the monarchy who were not noble had to be dealt with, even at the expense of logic. The idea of royal "recognition" of nobility was an attempt to paper over the granting of noble status to nonnobles. It covered the breaching of the system by claiming that these new nobles had been noble all along but memory of their genealogy had been accidentally lost. Thus in a society in which the efficacy of the idea of nobility as the legitimation of inequality depended on the genealogical principle, people were becoming noble all the time. And by 1600 , noble titles were being bought and sold.

Impurity also was fraught with ambiguity. In one sense, impurity was the expression of human sinfulness, something created in our original "nature." Here it had a genealogical sense. Yet nobles were, theoretically, always in danger of losing their purity. But if purity of blood directly imparted nobility to behavior, how could behavior leading to impurity arise? Social reality had to be dealt with. Any social ideology that does not allow powerful people to fall from preeminence is exceedingly vulnerable. There had to be an idiom for downward social mobility as well.

These ambiguities in argument about purity of blood and nobility reflect, in part, the necessity of adjusting a theoretical system to the complexity of a real society. While the legitimacy of nobility rested fully on the genealogical principle, the system had to accommodate the rise of nonnoble families and the fall of noble ones.

All the theoretical contortions notwithstanding, the genealogical principle could not account for social mobility. When egalitarian doctrines came to prevail in Europe, they did so, in part, by forcing this problem to its limits. If the nonnoble could rise and the noble could fall, then the environmental principle, not the genealogical principle, was the paramount force in society.

The continual tension between the genealogical and environmental principles is a fundamental characteristic of the humoral/environmental system for explaining "human nature." The two principles contest each other's turf but neither can displace the other. In Hippocrates they collaborate; during the Old Regime studied here, genealogy is argued against environment; and during the Enlightenment, as we 


\section{I | Complex Continuities}

shall see, environment comes to be argued against genealogy. And this nature/nurture debate has not yet ended.

\section{The Social Context of Nobility}

According to the great lawmaker and compiler of legal codes Alfonso X (El Sabio) ([c. I 265] I848:vol. I, Title XXI), society was naturally divided into three estates: clergy, military, and laborers. The first two estates were noble by definition; they could not have been otherwise, since it was their nobility that made them preeminent in religious and military matters. To hold a position of significance in the church or in the military, a person had to be noble. Within the nobility, there were distinctions of reputation, wealth, and power.

By the fourteenth century these principles were embodied in characteristic social institutions and patterns of social conflict. The documentation of claims to nobility became an extremely important function of the state; heraldry and genealogical investigation flourished as never before or since. All families that could make claims to nobility did so and insisted on the issuance of letters patent.

Because of their crucial role in military actions and governance in the late part of the Reconquest in southern Spain, the military orders (originally established for the Crusades) came to exercise important control over the process of granting letters patent. Ambitious individuals with sufficient wealth to receive a proper education found that admission into the military orders was a vital step. To secure admission an individual had to prove his nobility.

If the applicant did not have an established claim to nobility, the military orders instituted a complex investigative process. Genealogical research was undertaken to ascertain that there was no Moorish, Jewish, or heretic mixture in the man's background. Testimony was sought from acquaintances regarding his behavior, and investigators visited his town of origin to see his properties and to discuss his reputation with townspeople, especially to see that neither he nor his family had engaged in nonnoble occupations. The investigative panel then determined the nobility of the applicant, subject to royal confirmation.

There were other avenues to the social recognition needed for as- 
cension to higher statuses (preeminently through the church), but this example suffices to show how fully developed the administrative/legal apparatus surrounding grants of nobility was. The gatekeeping function of nobility was considerable and carefully exercised.

In any such institution, great opportunities for abuse exist. Enemies could make false claims about an individual's background and people could falsify their own claims to nobility. By the seventeenth century, letters patent and privileges were easily bought and sold. With enough money a person could become noble by either bribery or direct payment for a title (Caro Baroja 1966).

The nobility gained center stage with the beginning of the definitive administrative centralization of Spain in the fifteenth century. The issuing of letters patent, the development of complex rules for dealing with nobility, and the elaboration of legal concepts of nobility began to appear in great numbers by the time of Henry IV (I454-74). A significant number of claims to nobility were considered by Philip II (I 227-98) and his successors. Philip was particularly concerned with the problem of recognizing the "native" nobility in countries then incorporated in the Spanish empire. He used grants of nobility as part of a strategy of political alliances to operate his highly heterogeneous realm.

The central role of nobility effectively came to an end by 1700 , when wealth became more important than titles. Once wealth could purchase nobility unproblematically, the social value of nobility began to decline (Caro Baroja I966). This is not to say that society was becoming less stratified by 1700 ; rather the idiom of stratification was shifting from an aristocracy of blood to an aristocracy of wealth. Although wealth had obviously always been important to a family that aspired to nobility, by this time wealth alone, unadorned by title, could provide great social eminence. The social power of the genealogical principle had been undermined.

Blood and Nobility in the Basque

Country and Castile

Despite a shared conceptual framework and the use of the same literary and legal sources, the various regions of Spain appropriated 


\section{II6 | Complex Continuities}

and developed the concepts surrounding nobility in different ways. All accepted the causal role of purity of blood in creating existing social arrangements. Despite their use of common concepts for thinking about and legitimating social structures, regional political economy and the course of historical events ultimately differentiated the Basque Country and Castile so completely that they developed mutually opposed political ideologies. This point, central to the understanding of the process of ethnogenesis, shows that, even within an agreed-upon conceptual framework, highly differentiated social implications can be drawn from the same humoral/environmental theories.

\section{Nobility in the Basque Country}

The Spanish Basque Country is composed of the provinces of Vizcaya, Guipúzcoa, and Alava, to which Navarra is often added, all in the northeast corner of Spain. There are three other Basque provinces on the French side of the border. Speakers of a language unrelated to any other currently used in the world, the Basques have been in the news in recent years because of the political strife surrounding them, especially the waves of ETA terrorism. The Basque Country has a long history of provincial customary law and has characteristic institutions for local and regional government. The issue of nobility in the Basque Country was first joined in the development of these bodies of customary law. ${ }^{3}$

The conflict occurred in a resolutely political context: the forced development of a comprehensive written code of customary laws (fueros) acceptable to the Spanish monarchy. Until the time of this codification, the reigning monarchs had generally observed the customary laws without having a compilation of laws to refer to. The result was continual friction, since the actions of the monarchy were regularly held to be in violation of the fueros by the Guipúzcoan government and the monarchy always suspected that the Guipúzcoans were establishing legal precedents to avoid complying with royal wishes.

These laws were written down only when the persistently divergent interests of the crown and the province threatened their very existence. Apparently the first attempt to write down some of the fueros 
in Guipúzcoa was made in 1397 . Subsequently the body of written fueros was elaborated and recompiled as the changing political situation warranted, until in 1696 the crown demanded a definitive compilation to which no more could be added. These bodies of customary law, unwritten and then written, were of such importance that new monarchs, upon taking the throne, had to swear to uphold them.

The specific history of the fueros of Guipúzcoa is less important here than their political context. The compilations were organized as attempts to develop a comprehensive doctrine of provincial rights with legitimating philosophical and legal arguments. The written fueros were essentially defensive documents, and they became more complete and strident in their claims for provincial rights as the monarchy's desire to eliminate those rights increased. The maintenance of these fueros into the late nineteenth century was permitted by the unique strategic importance of the Basque Country in Spain (Greenwood r977).

In this defensive process, Basque jurists both compiled laws and set them in a comprehensive historical, geographic, and ethnographic context. A ruler who swore to uphold the fueros simultaneously ratified the Guipúzcoan view of history and ethnic identity. And in this view of history, the concept of nobility occupied a central place.

Nobility appeared early in the compilation in the second chapter of Title II. The document contains a comprehensive theological, legal, and historical argument, peppered with references to earlier thought on the subject. The three types of nobility were specified in detail and then an important step was taken. The Guipúzcoan Basques claimed that they were all bidalgos de sangre because anyone born in Guipúzcoa of Basque parents was noble:

Among all these types of nobility, that which really and truly refers to the founders of the Province of Guipúzcoa is the natural secondary, which is commonly called nobility of blood, because it is nobility that comes to persons through lineage. This honor comes to them by right and justice via inheritance from the first fathers of humanity. Although there are authors who with some basis assert that all nobilities originated in concessions by kings and natural lords, this general proposition does not fit well with the true origin of Guipúzcoan nobility, which ... is general and uniform in all descendants of its territories, without 
having been conceded by any of the kings of Spain, as is manifested by the lack of memory of such, or acquired by the means provided by law, or transplanted here by any of the many foreign nations that dominated this kingdom (since there would have been a historical record of it), but rather is conserved and continued from parents to children, inviolably from the first inhabitants of the Province to the present time.... [Nueva recopilación ... (1696) 1918:18 ${ }^{4}$

This interesting claim to collective nobility had multiple implications and justifications. The supporting arguments offered were mainly historical. The compilers of the fueros claimed that the Basques were the oldest inhabitants of Spain and were lineal descendants of Tubal. The second title of the fueros states:

About the beginning of the populating of Spain after the universal flood and about the location in which the descendants of the patriarch Noah first formed their habitation and home one finds no definite information in the gospels: but such [information], which is greatly detailed and strongly based on common authority [popular memory], exists [stating] that Tubal, fifth son of Japheth and grandson of the second father of humanity, was the first who came to this region from Armenia after the confusion of tongues in Babylonia, with his family and others, and that his first settlement and home was in the lands situated between the Ebro River and the Cantabrian Sea.... [P. I4]

Thus they argued an unbroken genealogy back to the fathers of humanity, an argument widely made in other tracts as well (Echave [I607] I 97I, Isasti [I625, I 850] I972, Zaldivia [I 5I7] I944). The physical purity of blood is an important element in this view. After the Flood, humanity had been purified of all but original sin. Those who could claim an unbroken genealogical connection to such figures as Tubal could assert their purity of blood and thus their nobility. Genealogy here attests to humoral purity.

The fueros also argued that the Basque area had never been overrun by the Moors, and that the Basques not only defended the area against them but were active participants in the Reconquest of Spain. Claiming to be widely known for their staunch Christianity, they used these combined religious and military arguments to support their claim that their genealogy went back to the beginning of time and that it had never been contaminated by Moorish, Jewish, or heretic mixture. 
The fueros and the supporting commentaries did not stop with this historical argument for lineal purity of blood. All of the sources carefully documented Basque participation in the Reconquest and encounters with the French (including Roncesvalles) and many others, all showing the preeminence of the Basques in military struggles. Great detail regarding the battles themselves was given, and most royal oaths to uphold the fueros mentioned Basque military prowess. The religiosity of the Basques and the large number of learned men the Basque Country had produced were also documented. Thus the fueros approached the proof of nobility from the side of right actions as well as genealogy. By their consistent right actions, the Basques legitimated their claims to nobility of blood.

Collective nobility is a most peculiar idea. A major function of nobility is to exclude most of the population from participation in elite institutions. The Basque claim to collective nobility by purity of blood forced the Basque jurists to argue that many people whose social roles would be direct impediments to nobility-farmers, fishermen, coopers-were noble. The Basque jurists pursued this position aggressively:

It should be noted that nobles of blood, particularly those of Guipúzcoa, do not lose their nobility through working in ordinary and necessary occupations, even if they have fallen into total poverty; because nobility of blood did not arise in them but came to them from their ancestors and lineage, and it is enough that it [nobility] should have produced its effect in the former even though at present it has ceased to do so.... But if the nobility is nobility of privilege, which is called ex accidenti, it is lost in the exercise of ordinary occupations.... It should further be noted that the noble who lives nobly, even if he is a rustic and works with his hands, does not lose his nobility. ... [Isasti (I625, I 850) I972:47; emphasis his]

This argument represents a fascinating play on the genealogical principle. To place their claim to nobility beyond the historical reach of the Spanish rulers, the Basque jurists argued that Basque nobility was a direct unsullied inheritance from the first fathers of humanity. But in the empirical world Basques necessarily occupied all social strata, many engaging in nonnoble occupations-a direct contradiction of 
the concept of nobility. To deal with this problem the jurists suspended the behavioral side of nobility entirely and stressed only direct genealogical connections to the first fathers of humanity. This strategy shifted the social function of the concept of nobility from an explanation of social stratification to a legitimation of regional ethnic rights.

The Basque claims were not made or taken lightly. The theorists of monarchy, even as far back as Alfonso $\mathrm{X}$ in the thirteenth century, argued that only a very few people, and perhaps no one currently, enjoyed nobility unless it were confirmed or granted by the monarchy:

There have been and are many who received nobility solely by being from particular territories and places that were noble by privilege and grace from Kings and Princes... . [He gives the example of the Roman cities in Spain.] The reason that these and other similar cities and places received this nobility was that they deserved that the Kings and Princes should concede it to them for the virtue, valor, and services lent by their inhabitants.... In this way the Vizcaínos [Basques], because of their great antiquity and invincible force and because of their heroic military actions, have acquired nobility for their country, in such a way that by only proving that they are original inhabitants of Vizcaya [the Basque Country], or descendants of such by legitimate and natural male lines, they receive letters patent of nobility of blood, because they truly are [noble] and are declared to be such, this nobility being confirmed by the Kings of Castile and León.... [Moreno de Vargas (I636) I795:30-3I]

The monarchy argued that any special privileges the Basques enjoyed must have been given to them by rulers. In other words, the rulers rejected the Basque claim to nobility of blood without royal confirmation, thereby rejecting the Basque claim of a unique ethnic identity. Had the Basques accepted this royal view, it would have been only a short step to a royal argument that Basque nobility was really only civil political nobility and could be revoked by the monarchy. In their counterargument, the Basques claimed to have been noble long before there were any Spanish kings to grant nobility.

At stake in this argument was an important political principle. If Basque nobility were subject to royal confirmation, and particularly if it were defined as civil political nobility, then the ruler who had 
confirmed or granted it could conceivably choose to revoke it. Arguing that their nobility was natural secondary and moral nobility without need for confirmation, the Basques moved politically against the rights of the Spanish rulers to exercise unconditional political power in the Basque Country. For hundreds of years this argument was a major ideological support to the demand for a semi-autonomous administrative regime in the Basque Country which would operate on the principles embodied in the fueros.

This is not to say that social hierarchy was absent in the Basque Country. The Basque Country was as socially stratified as the rest of Spain. Many noble Basque families that shared the collective nobility of all Basques were also civil political nobles with personal privileges that had been granted by Spanish rulers. Social classes and social conflict were certainly not unknown in the Basque Country. To romanticize the Basque past on the basis of a literal reading of the fueros is an error, a point amply developed in an unfortunately uneven book by Alfonso Otazu y Llana (1973).

The pro-fuero argument was not that all Basques were socioeconomically equal but that all Basques shared equally in a noble genealogy and the rights that arose from it. Collective nobility stressed the genealogical principle in its most radical form and treated the differing social positions of Basques as accidental environmental effects. In the Basque view, the concepts of nobility by virtue of purity of blood and collective genealogical equality were directly linked. Collective nobility became a naturalistic justification for a particular set of political arrangements in which the Basques were singled out for special treatment.

Nowhere is the manipulation of these principles clearer than in the Corografía ... de Guipuzcoa of Father Manuel de Larramendi ([c. r754] r969). Writing when nobility as a social ideology was on the wane and egalitarian ideas had begun to spread, Larramendi shifted the ground of the debate to stress the egalitarianism inherent in the idea of collective nobility and a representative form of government under the system set up by the fueros. All Basques are equal, he argued, because all are descendants of the same ancestors; and they are superior to the Castilians because they are all genealogically noble and Castilians are not. 
The intellectual foundations of the democracy he advocated are not those of contemporary democratic thought. Among Basques a unique degree of human equality was asserted to exist. People from all stations in life had similar claims to human dignity, claims supported by the Basques' reading of the egalitarianism of Christian salvation. But this equality existed, theoretically, only because of purity of blood, because of the unsullied Basque genealogy. Thus the Basques saw themselves collectively as an elite. Their only equals were the monarchs and nobles of the rest of Spain. The common people of Spain were inferior to them because their blood was impure. The genealogical principle here takes a racial turn. Perhaps the most apt comparison is with the "democracies" of antiquity, which limited participation to a certain group of people.

Basque collective nobility was an extremely difficult problem for the monarchy. In swearing to uphold Basque customary laws-as the Spanish monarchs repeatedly did in an attempt to contain their fiscal and military problems - the monarchy actually ratified the Basque view of history. Royal subjects in other parts of Spain complained bitterly about Basque rights, arguing that such rights should either be extended to all subjects or withdrawn from the Basques. It was not until the latter part of the nineteenth century that the fueros were officially canceled. And now, with the new constitution, the fueros are once again a political reality.

\section{Nobility in Castile}

Castile is the central region of Spain, made up of the provinces of Avila, Burgos, Logroño, Santander, Segovia, Soria, Valladolid, Palencia, Ciudad Real, Cuenca, Guadalajara, Madrid, and Toledo. Its historical trajectory was quite different from that of the Basque Country. Not only did Castile dominate Spain politically from the late fifteenth century on, but earlier it was almost completely overrun by various Muslim groups (called Moors in the literature). Parts of it were under Muslim control for periods of from I 50 to 700 years. A substantial Jewish presence in Castile is also well documented (Caro Baroja 1978).

The ink and blood spilled over the Moors, Jews, Old Christians, Moriscos, Christianized Muslims, and converted Jews is familar enough. 
It is important to understand, however, that the arrival of the Muslims and the subsequent intermixing of populations forced the question of nobility to take a distinctive form in Castile. Except for a very few preeminent families with wealth, property, and documents sufficient to forestall questioning of their ancestry, virtually no one in Castile could simply assert nobility by virtue of genealogically transmitted purity of blood.

In this historical context, the role of the confirmation of nobility of blood through letters patent and the granting of civil political nobility became tremendously important. By judicious use of these powers, the monarchy could partly control the powerful and militarily dangerous families that were competing with the crown for power. At the same time, the Reconquest offered a field of honor on which wealthy and ambitious men could do battle. Through their valor they could win the gratitude of their rulers-gratitude that took the form of letters patent or grants of civil political nobility.

Thus the Castilian conception of nobility was almost exclusively military. This attitude could be seen as far back as Alfonso X. Of course, such nobility could be won by only a small segment of the population, since wealth, education, and staff were needed to mount a successful military career. Nobility thus became the principal symbol for social hierarchy. While genealogical connection was obviously important and a broken genealogy could eliminate a family from the ranks of nobility, de facto social eminence or military virtue was necessary for a successful claim to nobility.

Once the major noble families were well entrenched in Castile, their various lines quickly came to control both military and religious institutions. They participated in the establishment of bureaucratic procedures for determining nobility and for granting letters patent. These procedures were used effectively as a device to keep nobility and its privileges a significant monopoly of the few against the many.

The privileges of a nobleman were very considerable. The following list is typical:

monopoly of high offices

monopoly of diplomatic positions

monopoly of command at forts and castles 


\section{$\mathbf{2 4} \mid$ Complex Continuities}

no payment of taxes except for public works of benefit to them no confiscation of property for payment of debts no imprisonment for debt

if convicted of a crime, jailed differently from nonnobles could not be tortured

if called to testify in a legal action, testimony taken at their pleasure outside the court

free to refuse challenges to duels from nonnobles could force the sale of certain properties to themselves after judges, would receive the best seating at public events

[Moreno de Vargas (I636) I795:Discourse I2]

At least on the ideological level, the confirmation of noble status clearly carried significant social benefits in Castile. How extensively these rights were actually exercised cannot be inferred from this kind of documentation, but the ideal rules show that nobility conferred social preeminence. By implication such documents also indicate the vulnerable social position of the nonnobles in Castilian society.

In the logic of this system, the rulers and their lieutenants occupied a crucial position. Since virtually all nobility required confirmation or was granted as an honor, the control of nobility became a central instrument of monarchical control in Castilian society, helping to forge an alliance between the nobility and the monarchy against the segments of the population that had wealth and power but were not loyal to the crown.

The Castilian system rested firmly on the principle that human inequality was a profoundly important "natural" element in society. Because men were not naturally equal, the rulers, clergy, and nobility governed in the interests of the majority who were their inferiors. In this case the genealogical principle was used to exclude most classes of people from access to positions of power. Purity of blood was here an instrument of social hierarchy, while in the Basque Country it was used as an instrument in defense of regional rights.

\section{Conclusion}

The Basque and Castilian views are similar in important ways, despite the major differences in their social application. Not only do 
they use the same humoral concepts and encounter the same problems created by the conflict between the environmental and genealogical principles in humoral/environmental explanations, but both use purity of blood as a principle of inclusion/exclusion. In the Castilian case, purity of blood excludes all but the few from positions of social dominance. In the Basque case, purity of blood includes all Basques in order to set them apart from and in a position superior to the nonnoble Spaniards. By this kind of logic, though this statement exaggerates the case, the Basques are to most of Castilian society as the Castilian nobles are to Castilian society.

This general picture of social stratification could be duplicated throughout Europe in this period, and references to the relationship between social position and the physical qualities of the blood in the veins of the population can be found in most countries. Without the humoral theory, none of the arguments would make sense.

Thus the humoral/environmental theory both explained and justified existing social systems. These naturalistic ideas were linked to powerful social forces. Basques versus non-Basques, nobles versus clergy versus laborers, nobles versus commoners-all such contrasts were treated as social expressions of natural categories. Each category of people was as it was because of the way it was created and the history it has experienced. Natural nobility did not come into being; it was created and either remained pure or was degraded.

The contradictions in the various views of purity of blood can be understood as expressions of the ambivalence between the genealogical and environmental principles in humoral/environmental theories. Purity of blood automatically caused noble behavior, but then some Basques could be noble but behave like commoners and some commoners in Castile could act in ways that caused them to become noble. These are the contradictions found in the Hippocratic texts. Humoral/environmental theory virtually always involves these contradictory relations between nature and nurture.

There is a very strong emphasis on the notion that unambiguous natural categories of living things (in this case, classes of people) exist. All individuals are, in a sense, simply embodiments of these categories. The categories are static, having been created once and then reproducing themselves thereafter. Most of the conflicts between the 


\section{I26 | Complex Continuities}

genealogical and environmental principles are caused by attempts to reconcile this static view of the categories with the known changes in social status that families and individuals undergo. Finally the "natural" hierarchy, by virtue of its being "natural," is therefore asserted to be morally correct. The step from "is" to "ought" is made without trepidation.

Concepts of blood and purity in no way exhaust the uses of humoral/environmental ideas to explain and legitimate social systems and human behavior. Bile, both black and yellow, and phlegm also have long and interesting histories. But the working out of the concept of blood suffices to indicate the structure and importance of humoral/environmental theories as naturalistic explanations and legitimations of social systems. 


\section{CHAPTER 5}

\section{An Enlightenment Humoralist: Don Diego de Torres Villarroel}

While the specifics of the naturalistic arguments in support of hierarchical social structures are no longer familiar, this use of "natural" differences is. In the twentieth-century struggles over racism and ethnocide, oppressive exclusionary social theories based on "natural" differences between humans have been widely employed. This contemporary social experience has led some thinkers to assert that any theory of society containing naturalistic arguments must be inherently oppressive (e.g., Ann Arbor Editorial Collective of Science for the People I977).

While it is true that many oppressive social theories contain naturalistic elements, the connection between naturalistic arguments and oppression is not direct. Naturalistic theories in general and humoral/ environmental theories in particular are not inherently biased in favor of social hierarchy and oppression. Such views can be and have been used to buttress democratic and populist doctrines as well. Many democratic theories assert that all humans are born equal and therefore have equal rights. Is this position any less naturalistic than the racist counterposition that whites are born superior to other races and therefore have more rights? 
Apologists for the failure of democratic ideas to capture the minds of a great many people often lament that racist/oppressive doctrines are intrinsically more attractive to most people. But if naturalistic arguments were once capable of fueling popular support for social reform, why do they not do so now?

These issues are joined in the ideas of a Spanish Enlightenment thinker, Don Diego de Torres Villarroel, who participated in an important and well-documented struggle over the social and moral consequences of humoral/environmental theories in medical science. Torres mobilized humoral/environmental theories to support popular medicine against the existing state monopoly of medicine and used these ideas to denounce a host of social inequities, thereby demonstrating that these theories are not inherently biased in favor of social inequality.

\section{Humoral/Environmental Ideas in Medicine}

Each of hundreds of schools of medical thinkers contributed its own version of the medical meanings of humoral/environmental ideas. This multiplicity of uses is a sure indication of the fruitfulness and importance of these theories.

Galen's development the humoral/environmental tradition embodied in the Hippocratic corpus, with the inclusion of Aristotelian and Stoic elements, gave rise to a complex medical system complete with an elaborate pharmacology. During the Middle Ages the humoral/ environmental tradition persisted through the Arabic renderings of the original ideas. The so-called Arabized Galenism of Avicenna is a case in point.

With the Renaissance return to the original Hippocratic and Galenic texts, the stage was set for a long polemic. The filtering of humoral/environmental ideas into Western folk medicine, the variety of medical traditions derived from Arabized Galenism, and the ferment created by the reading of the original texts set the medical world in motion. The competing schools based their ideas essentially on different readings of the same basic texts. When Arabized Galenism is compared with the Galenism inspired by a direct reading of Galen's 
texts, it appears to be a completely different, radically opposed school of medical thought and practice. Hippocratics, Galenists of all kinds, "physicians," "chemists," and herbalists flourished and did battle. Yet despite this ferment, the pace of change in the medical schools was slow. Most medical schools persisted in complex, philosophically abstract medical theorizing long after real alternatives had been suggested.

These developments set the stage for the Enlightenment attack on institutionalized medical thought and practice. Enlightenment thinkers familiar with the classical texts were persuaded that medical knowledge and practice had to be concrete, empirical, and individualized. The purpose of medicine was to understand an illness and to collaborate with the inherently harmonious forces of nature in getting the patient well. For these thinkers, the abstract philosophical training that doctors received and the regular medical use of strong drugs and bleedings were major causes of death.

The tendency of historians and philosophers to overlook the immense social and intellectual influence of physicians was noted earlier in regard to Hippocrates. Physicians, certainly by the time of the Enlightenment, were viewed as scientists and professionals, and their social and political views carried great weight. Long before Darwin, scientists were considered important social thinkers. ${ }^{1}$

\section{The Life and Works of Torres Villarroel}

Diego de Torres Villarroel, born in Salamanca in I694, was professor of mathematics at the University of Salamanca. But he was more than a professor: he was a qualified medical doctor, a priest, natural scientist, poet, dramatist, essayist, the most famous Spanish astrologer of his time, dance instructor for a brief period, administrator of some of the Duke of Alba's property, and philanthropist.

Torres was an unabashed admirer of his famous literary predecessor Francisco de Quevedo; many of his literary works are attempts to mimic the works of the great seventeenth-century Spaniard. Yet with a few erudite exceptions, Torres' works are largely forgotten. His overpowering satirical style and continual sermonizing make his fifteen- 
volume complete works less than easy to read. Only two of his works have remained in print since they were published. Since 1977, two more have been reprinted. ${ }^{2}$ This fate seems partly deserved, but literary criteria of evaluation have seriously obscured the larger historical lessons to be learned from Torres' more scientific work. ${ }^{3}$

This immense and heterogeneous corpus is a rich lode for the anthropologist and historian of science. It articulates a coherent vision of the world, society, and the human condition in which cosmology, theology, ethics, natural science, medicine, and social criticism are linked. Of particular interest is a strong current of social criticism based on a kind of moral egalitarianism. And in all these dimensions humoral/environmental ideas play a critical role. ${ }^{4}$

Torres' father was a bookbinder. Though the elder Torres was well respected in Salamanca and ultimately served the city in important administrative posts, these are most modest beginnings for someone who was to become a university professor (as Torres never tired of reminding his readers). In 17 I 5 Torres took the first formal step toward becoming a priest, but he did not seek ordination until thirty years later. Torres' literary career began in $17 \mathrm{I} 8$ with the publication of his first astrological almanac. He published one a year until $\mathrm{r}_{753}$, earning much fame and money, a fact he liked to point out from time to time.

The year $17 \mathrm{I} 8$ marked his first visit to Madrid, where he was eventually to reside for some years. There he engaged in medical studies and made powerful friends among the nobles. He completed his medical studies but determined never to practice medicine, a promise he broke only a few times, under the pressure of poverty. In 1726 Torres acquitted himself well in the competitive public examinations to fill the chair of mathematics at the University of Salamanca, but he had to wait eight years until the death of the previous incumbent freed the funds to permit him to fill the post.

Torres was involved in more than his share of conflicts. By his own admission, he was a rascal. In $\mathbf{I} 732$ he was exiled to Portugal for his participation in an event that has not been clarified in his autobiography or by any of his biographers. But he returned in time to fill the chair of mathematics in $\mathbf{1 7 3 4}$. Though he evidently was a good teacher, he was a trying colleague. Always conscious of his social origins, he 
saw himself as an intrusive foreign body in the university. He never tired of attacking the pomposity of the other professors. The university records show that Torres was often absent in Madrid, a point his enemies endeavored to use against him. But the records also show that Torres was regularly entrusted with complex, important duties by his colleagues, duties that required the mobilization of his contacts in Madrid.

In 1745 he finally determined to be ordained as a priest. This decision was accompanied by a severe illness, a point that has given psychologically oriented biographers much to speculate about.

He retired from his professorship in $175 \mathrm{x}$ but remained active in university affairs practically till his death, in 1770 . During his retirement Torres saw to the publication of his complete works, an effort amply supported by an impressive list of subscribers. He also became an active supporter of charitable institutions in Salamanca and a member of the household of the Duke of Alba.

Torres' corpus can be divided into three clear categories: cosmology-astronomy-astrology, natural science, and medical/moral works. A large fourth category consists of miscellany. The cosmologicalastronomical-astrological works are diverse. From the physical structure of the universe to almanacs and star charts, Torres covered a wide array of subjects. The almanacs contain attempts at weather prediction with frivolous (according to Torres himself) predictions of events. But he sincerely believed in the influence of astral bodies on the earth and on the physical condition of living things, and constructed astral tables for public use.

His natural science interests were also diverse, covering such topics as beekeeping, geology, the causes of earthquakes, the sources and uses of mineral waters, and why a rooster transported across European time zones crows at a particular hour. These works convey great enthusiasm for empirical science and a desire to communicate the findings of natural science to the general public.

Torres' medical/moral works combine medical manuals written for the lay public, literary works with a powerful emphasis on health, and extraordinarily harsh criticisms of medical education and practice.

The miscellaneous works form a bewildering array. Among them is 


\section{I32 | Complex Continuities}

Torres' well-known autobiography, published between I 743 and I 758 . In it he justified himself, poked fun at his own foibles, and evened many old scores. He also wrote lives of saints, plays, poems, and even an essay on bullfighting.

\section{Cosmology and Natural Science}

For Torres, natural science's empirical, inductive methods served to disprove many ancient commonplaces and measurably to improve the general quality of life. This part of Torres' corpus is enormous. These works rest on a consistent cosmology in which the structure of the cosmos, astronomy/astrology, and natural science are tightly interwoven. For Torres a theory of the material structure and operation of the cosmos was the necessary context for astronomy/astrology and by extension for the study of natural phenomena on earth, such as earthquakes, the humors, and the habits of bees and roosters. Thus to be understood, his humoral/environmental theories must be placed within this larger context.

In Cartilla rústica (Rustic note) Torres portrayed himself as the teacher of a peasant who was to use his new knowledge to improve the quality of life in his home village. To begin the instruction, Torres diagrammed the cosmos as a set of twelve concentric spheres with the earth in the center.

I showed it to him, explaining with circles the order of the spheres. My good peasant looked at them for a long while, and then he said to me: "So we are inside of Heaven?" "Yes, friend," I answered, "and inside of the air and fire, and everywhere we are surrounded by and united with these elements, each to the other, and then to the heavens; and just as the layers of an onion hold together, so this marvelous machine is maintained by natural virtue." [Torres Villarroel $1794-99,6: 166]^{5}$

Through this conventional image, Torres explained that the cosmos is orderly, hierarchical, and totally permeated by the four elements. The entire system is perfectly balanced.

This general vision was associated also with the complementary view of the macrocosm and the microcosm. In his Anatomia de todo 
lo visible e invisible (Anatomy of all things visible and invisible) Torres took some companions on a fantastic voyage to the center of the earth.

And by the grace of God we have seen the organic body of the Earth and we have anatomized its principal cavities, which without doubt have a great similarity to the human body; for the surface of the Earth is like the skin or hide covering these cavities or regions: the lapidary or mineral material is the skeleton that supports the musculature or fleshy part of the Earth, like the bones of the human body; the four humors that swim inside of humankind are found here; for what else is salt water but phlegm? What is sulfur but choler? What are these black and toasted potions other than melancholy? And finally, what are the veins but conduits filled with the most precious liquor that arises from the distillations that occur in these depths, just as the stomach digests food?... [I:56]

In this way Torres asserted that from the macrocosm to the microcosm, the material basis of all things and the operating principles are always the same.

El hermitaño $y$ Torres (The hermit and Torres) elaborates this notion. The entire system is a harmonious whole in which the four elements play a principal role.

... all things of the world, great and small, be they natural or artificial, must sustain in themselves the four humors. Then each, in larger or lesser degree, must emit the selfsame virtue, and when introduced into our bodies, they will nourish them, purge them, they will cause drowsiness or wakefulness, and they will stimulate all other good or bad, healthy or sickly operations that we all sense-the happy and the afflicted, the young and the old the living and the dead-in our human bodies. For all creation concurs to give us health, illness, sadness, pleasure, life, and death. [Torres Villarroel I977:I 80]

This idea was further developed in Cartilla astrológica y médica (Astrological and medical note) (1794-99, vol. 6). After setting the cosmological context for humans, Torres presented the "four natural virtues": generative, vital, animal, and natural. The generative virtue is under the influence of Venus, the vital under the control of the sun. Animal virtue is not associated with a particular astral body here. Rather it is divided into two realms, each associated with particular 
primary qualities of matter. The two realms are the cognitive and the sensual.

The cognitive realm is divided into imagination (hot and moist), fantasy (cold and moist), knowledge (hot and dry), and memory (cold and dry). In the realm of the senses, sight is associated with cold and moist, hearing with cold and dry, taste with hot and moist, smell with hot and dry, and touch with a mixture of all four qualities.

Natural virtue, now as one of the four natural virtues, is divided into the four humors, each under a particular astral influence: blood (Jupiter), phlegm (the moon), choler (Mars), and melancholy (Saturn). The possibilities for metaphorical combination and opposition in such a system are immense. At the same time the macrocosm $/ \mathrm{mi}$ crocosm link is pressed to its limit.

Torres' system contains nothing unique or new. He was a firm believer in humoral/environmental theories, and they formed the basis of his cosmology, natural science, medicine, and even theology (in part). These beliefs explain his interest in astronomy/astrology (Torres did not differentiate the two clearly). Within the structure of his cosmology and the universal operation of humoral/environmental principles, astral influences are a logical necessity. If the universe is a set of twelve circles with the earth at the center and if the material principles of all processes are the same, then logically movement in any one of the twelve spheres will influence the others, and the larger (outer) spheres will more strongly influence the smaller (inner) ones. Thus Torres believed in astral influences as a matter of scientific faith.

\begin{abstract}
All lower bodies depend on higher ones, the earthly on the celestial, and among them they sustain a mutual kinship and obedience. The superior bodies send down a particular hidden active virtue to the inferior ones, and because of this, the humors and elements of the organic bodies of man and beast shift, are altered, become corrupted, or increase according to the position and quality of the stars: and we know this from daily experience, the best teacher of all things. [Torres Villarroel $1794-99,6: 13]$
\end{abstract}

\section{The Human Condition: Theological/Moral Populism}

Humans, as both material and spiritual beings, must live at once in two realms that are difficult to reconcile. In Torres' view, the spiritual 
realm is the more inclusive; the body is a momentary part of the soul. The body, as part of the soul, necessarily must be respected, and this respect must take the form of treatment in accord with the general material principles of the universe. The punishment for failure to respect the body is physical torment and death; for failure to respect the soul, moral anguish and eternal damnation. Failure to respect the body is an important step toward eternal death. ${ }^{6}$ Yet even the most judicious attention to the body cannot protect it from death. "My whole body is a portable infirmary of humors. I am sick. And ruined by nature. I am sick. That is why I have laughed at medicine for being so foolish as to presume to give health to mortal man" (Torres Villarroel I794-99, 3:34).

Individuals have different humoral constitutions, react differently to material forces, and have different strengths and weaknesses. Care of the body must always be empirically adjusted to the constitution of the individual.

Torres insists throughout his works that illness is no respecter of social class. He treats illness as a portentous reminder of the fleetingness of moral life and its honors. Illness highlights the need to attend to the soul's business. Indeed, Torres often seems to feel that wealth is great danger, because the rich face more temptations and can afford more vices. Occasionally he romanticizes the simple life of the countryman, who passes his life in hard work and simple pleasures.

Torres' social criticism must not be overestimated. His egalitarianism derived necessarily from his belief that all humans are equal before God, not from a desire to promote social revolution in this world. Still his egalitarianism and social criticism, combined with the repeated references to his own humble origins, at least place him in the intellectual tradition that flowered in the great democratic revolutions.

The work that best stands as a summary of Torres' view of the human condition is Vida natural y católica (Natural and Catholic life. ${ }^{7}$ Consonant with his ideas, the book was written as a self-help manual for the general public. The first of its two major sections deals with "natural" - that is, physical-health. Torres describes in great detail hygienic and dietary practices designed to maintain bodily harmony. Here humoral/environmental theory is the key element as he passes from diet, exercise, sleep, and excretion to mental health. General 


\section{I36 Complex Continuities}

precepts are given, but always with the caveat that they must be adjusted to the constitution of each individual. In the second part of the work Torres takes up the precepts to be followed to maintain spiritual health.

Perhaps the strangest and most interesting work of all is Los desahuciados del mundo y de la gloria (Those evicted from the world and from glory). Torres is taken by a devil on three journeys to witness the agony, physical death, and damnation of a variety of people. Both sexes, various social classes, and various diseases are represented with astonishing clarity. In each case the clinical side of physical illness and death is presented in excruciating medical detail. Indeed, this apparently disproportionate interest in physical illness clearly spoils the work for many literary audiences. But this detail is integral to Torres' thought about humanity as a "portable infirmary." The multitude of ways in which illness can attack and the helplessness of medicine must serve to persuade the audience that the only final salvation is spiritual.

Following the clinical portrait of each illness is an equally clinical portrait of the causes of the individual's spiritual damnation. All of the patients are damned, and the portraits of the demonic hosts mimic those of Dante. It appears that the physical neglect that led to illness was a symptom of a deeper spiritual neglect. Thus the message of the two parts of Vida natural y católica is repeated. Torres was pitiless and repetitious in his condemnation of degradation of the body and of the soul.

The remedies for these ills are within the reach of all people, rich and poor alike. The rich are particularly blamed for their behavior because they have the resources to live correctly and often do not. The poor can be excused in part for their ignorance, as few writers have directed their attention to humble audiences. Torres' desire to communicate these lessons to the humble is an indication of his moral populism. This attitude becomes most pronounced in his criticisms of medicine.

\section{Critique of Medicine}

Torres' attitudes toward medicine were rooted in his humoral/environmental ideas, his profound belief in empirical science, and his 
populism. No specific element of his critique is uniquely his own. His particular criticisms of medicine and his theoretical points of departure were widely shared, as the writing of Martin Martínez (I748) and Benito Jerónimo de Feijóo (I 724-39) attest. What makes Torres' views interesting is his combination of widely shared criticisms of medical education and practice with a consistent attempt to create a "naturalistic" medicine "for the people." Within the total corpus we find an immense array of scathing denunciations of medicine.

The medicine that is studied in the universities is a vocabulary of terms that sound good and do ill, are worth little and cost much, and they sell us their knowledge so dearly that they generally cost us our lives. [Torres Villarroel 1794-99, 4:200]

I read Hippocrates, Galen, Willis, Sydenham, and the bravest of the old and new schools, and I did not find in them a medicine powerful enough to stop the running of a catarrh. In their books and among the doctors, one finds prescriptions to sell, not medicines for curing. Since I began to realize the little science man has in regard to man, animals, and the mineral and vegetable realms, I lost faith in the Aphorisms and I have decided to die by my diet, which is a doctor and medicine that is both cheaper and less disgusting. [4:199]

"But tell me, is it not possible that they [the doctors] have a certain basis on which to found their conjectures?" "Not at all," I said. "If they could prove their ability to cure even the least serious illness, the doblones would not fit in their purses. It is a misfortune and an unhappiness how short is their science, considering how long they have studied the art. And so, when ill, I do not order the most famous doctor to be called, but rather the first that passes by the door; all doctors are good and medicine is bad." [2:345]

A major emphasis in Torres' critique was the weak empirical foundation of medicine. He felt that medical education emphasized philosophical abstraction at the expense of empirical research. The scientific pretensions of the medicine of his time thus were to him intolerable pomposities and genuine physical dangers. He counseled good diet and living habits as the best, and certainly the safest, medicine.

Torres portrayed doctors as a dangerous luxury that only wealthy societies could afford.

No one knows medicine; it is said to exist, but no one knows where it lives. The doctor is a political fraud who serves to decorate republics, 


\section{I38 Complex Continuities}

not to cure illnesses; he attends to the ill but does not cure them; he is a witness to the triumphs of nature, the miracles, and the deaths. So if he is infallible and you, sir, are abandoned on all sides, conform yourself to necessity, finish your trip to the other world, die like a Catholic, not like a savage. [4:197]

The doctor does not cure, he merely witnesses the course of the disease and charges for his observation. And doctors have clients because of the cowardice of people faced with pain and death.

Torres' criticism goes further. Doctors are even active agents of illness.

If you are healthy, to seek the doctor is to solicit all illnesses: if you are ill, it is to seek the greater unbalancing of your humors, and to achieve a dubious relief, you will have to endure evident risks and very notable changes. Believe me that the ills of the body are felt and known to all, but no one can cure them. He who places his confidence in the aphorisms of nature and in temperance will be better cured than he who places his pulse in the hands of doctors. ... In the hamlets they do not use doctors, and the locals live more robustly and longer.... Thus if you call him [the doctor], you well can throw your fate to the winds, prepare your patience, and deliver your stomach to concoctions, garbage, and brews, your feet and arms to the barber, and your body to the parish church.... More die attended by a doctor than without medical assistance.... You need a confessor more ... he has the true and undeniable medicine, while for the illnesses of the body, there is no known antidote. [3:39I-94]

Torres firmly believed in medical self-help and in the obligation to care for oneself, physically and spiritually. No one can know us as well as we know ourselves; the expertise of doctors is a fraud.

What is important for us to know is clear to all: it is the very science of souls, and in that science only he who seeks his own counsel is erudite. The study of medicine begins with knowledge of our architecture and economy: my body is closer to my own scrutiny than that of another.... With no more effort than the prudent appreciation of the voices and shouts of natural reason we will know our ailments and their cures better than the doctor; and we are able to care for ourselves better than he can. [4:7-9] 
Doctors are political enemies, permitted by republics for the sake of variety, not out of need. Illness remains in the body, and the doctor comes and goes, and the illness remains until it wastes the humor away or nature, embarrassed and bored by the gravity of the treatments, heals itself. $[4: 84-85]$

Torres' critique of institutional medicine was partly designed to convince ordinary people of their ability and duty to fend for themselves. Not only was institutional medicine bad, but what little knowledge there was did not find its way to the people; it was hoarded as a lucrative medical monopoly. Vida natural y católica, Recetas de Torres (Torres' prescriptions), Médico para el bolsillo (Pocket medical handbook), and the various Cartillas (Notes) were all written as medical guides for the general public. This popularizing intention is proudly stated in each work. All are written in Spanish rather than Latin, and the language is reasonably simple and direct. Torres believed that people could be their own scientists, their own doctors, because the relevant knowledge was directly available through empirical observation and simple induction. Empiricism and populism were thus linked.

Torres believed that popular medicine would necessarily have certain characteristics, derived from humoral/enviromental theory. Such medicine would be based on nonradical, nonintrusive treatments that supported the "natural harmony" of the body. Diet, environmental change, exercise, rest, and meditation were the keys. Many of Torres' ideas could pass muster among contemporary holistic and naturalistic practioners.

Occasionally Torres, like many contemporary believers in naturalistic medicine, flirted with the idea that most serious medical problems were caused by the "unnatural" way civilized people live.

Those who dwell in this village are generally of more than medium stature, refined appearance, good color, well built, strong, and happily healthy: this is because those who limit their lives to a simple diet, accompanied by the sweet fatigues of their labors, live eighty and ninety years without the cares of ordinary illnesses and without the damages often incurred in social gatherings, libations, and the liberties of cultured civil society. [5:368] 
Although Torres approached popular medicine from many angles, his works on the uses of mineral waters provide the best overall synthesis of his medical ideas. Two monographs on three mineral springs in the province of Salamanca link his cosmology, geology, natural science, and social criticism into a general humoral/environmental vision of the human condition. The first monograph, published in 1744, is titled Usos y provechos de las aguas de Tamames y Baños de Ledesma (Uses and benefits of the waters of Tamames and baths of Ledesma). Though Tamames has been abandoned, Ledesma is now the home of one of the largest and most modern spas in Spain. Torres dedicates the monograph to the owner of the lands where the springs are located. This dedication evokes most of his humoral/environmental vision.

The famous spring ... is a fertile treasure and an endless mineral source that God chose to place in the territories where your excellency is the legitimate Lady, in order to add good fortune, blessing, and happinesses to your most illustrious house. Its waters are a delicious and most pure balsam, through which those suffering the misfortunes of illness recover the natural balance of their humors, the restoration of their lives, and a robust resistance against the ills, corruptions, and upsets to which our miserable weakness condemns us. [4:230-3I]

After detailing the properties of the waters, Torres asserts the reasons for their curative powers: "Water, in my understanding, is nothing less than a liquid powerfully suffused with the virtues of the stars, airs, metals, branches, seeds, animals, and all things visible and imaginable in the lower and higher realms of the world" (4:237).

Each person must be treated individually because people's constitutions differ, and the treatments must be explained in language intelligible to the ordinary patient.

I do not stop to define, divide, or discourse like the hidebound Physician; nor do I increase the number of aphorisms, examples, or authorities because to do so is to spend time and paper uselessly. As a practical, mechanical, and rigorous observer, I prescribe to the ill, some who must drink and others who must bathe in the waters, a tailored and useful regime, a sure and inoffensive diet, a moderate daily plan during the cure; and for afterward I give them consolations and rational hopes 
that help them achieve spiritual health and serenity, calm their apprehensions, and leave no room for melancholy. I also put these precepts in ordinary language and in the clearest doctrine so that even the most uneducated patient can understand and govern his body and its ills with no more doctor or aphorism than those found in the directions on these pages; I have founded the whole utility of this doctrine on this intention. [4:233-34]

... ordinary water serves and cures all kinds of people, the ill and the healthy, be they cholerics or melancholics, phlegmatics or sanguinaries, because it was created for all and for all it is prepared, disposed, congenial, and suited to their ills and good health. [4:239]

... I wanted to give it to them in writing so that all patients could carry with them a cheap doctor; because not all who go to drink or bathe can bring a salaried doctor with them. [4:234]

He strongly criticized the doctors of the University of Salamanca for not having made the public aware of these waters and their uses.

In 1753 Torres wrote again on mineral waters, in Noticias de las virtudes medicinales en la Fuente del Caño de la Villa de Babilafuente (News of the medicinal virtues in the Fountain of the Spring of the Village of Babilafuente). This spring is still in use. Here the same general themes are repeated, and the criticism of organized medicine is even sharper. In a prologue addressed sarcastically to the "Deceased Doctors of the Medical Schools of Spain" he denounces the stupidity and even criminality of systematic medical ignorance of the uses of mineral waters, especially in view of a standing request by the Royal Practical-Medical Council for such information.

To the Members of the Royal Practical-Medical Council of Our Lady of Hope in Madrid. It is also a letter that aspires to be a Prologue. To the Deceased Doctors of the Medical Schools of Spain: Dear Sirs:

Some because they lived lost in the foolish delights of their useless speculations, others because they blindly delivered all their gullibility to the potions, mixtures, and juleps that they found in the prescriptions in their books, and the majority of them because their imagination was occupied with other interests, more important than these trifles of public health, none ever remembered to investigate the virtues and effectiveness of the infinite medicinal springs that the industry and effort of nature created in their territories for the alleviation of many ills. Those 


\section{I42 | Complex Continuities}

living today, some because they inherited their complexions and certainties with the portfolios and maxims [of their predecessors], others because they presume that study, maturity, and experience are superfluous to their practice because they already have the repertoire of gestures, refrains, and ponderations needed to send the layman to the other shore, nurtured themselves on nonsense and ignorance, believing them to be prodigious truths, and have refused to involve themselves in the examination of these precious novelties, nor have they responded to your letter in which you request information about the origin and constitution of the healthful waters whose currents emanate in their regions. The utility of knowing and using the waters is visible, demonstrable, and advantageous to the world; because in truth, these springs are small, clean, easy, safe, and cheap Apothecaries, in whose fountains and currents are found a marvelous mixture of substances, chosen by the prolixity of nature and free of the impure mixtures and adulterations that are found in the compositions created by the Chemist's whim....

The public (Dear Sirs) is the first and most naked community in the world: it is the pauper, the uninstructed, the patient, and the invalid that is most visible and deserving of our contributions, goods, documents, and efforts. [5:363-65]

These virtually unknown essays on mineral waters clearly reveal the structure of the thought of this Enlightenment humoralist. The material cosmos created by god; the geology of the earth giving rise to airs, waters, and places; the humoral conditions of human life; and the battle against socially oppressive and morally inexcusable manipulations of knowledge are linked in a single, consistent pattern of thought.

\section{Conclusion}

This excursion into the works of Diego de Torres Villarroel provides a broad sense of the symmetry and interpretive scope of humoral/environmental theories. Torres' entire system is characterized by consistency and balance. Still Torres' system of thought is clearly nonevolutionary, in the same way as is the system used to explain and justify the preeminence of the nobility. In his view the natural world 
was created once and for all by God and has not changed significantly since then. His faith that empirical investigation would yield useful results is based on a belief that the Creator is beneficent and that his creation is formed of clearly defined, stable classes of things. The natural order is a moral order by definition.

Torres' thought is also characterized by tension between genealogical and environmental principles. He clearly believes that a great deal can be accomplished by manipulation of the environment, and in that sense he differs greatly from earlier Spanish apologists for the social order. His approach to popular medicine is informed by a belief that sensible diet and lifestyle can greatly improve health. That is, he believes environmental manipulation can have important effects on health. His critique of medicine also implies that people who permit themselves to become overintellectualized (as the academic physicians had done) can lose touch with the principles at work in the world. Poor training could only have the power to create poor doctors if the environmental principle were a potent force.

Together two very different deployments of humoral/environmental theories show that these views have a very broad scope. Humoral/ environmental theories are complex, flexible, and diverse-and they also have a pleasing overall integration. At the extremes, they have given rise to arid abstract scholasticism and mindless empiricism. They still hold astonishing power in the Western world, as the currency of some of the concepts used to justify nobility in current racist ideologies and the apparent similarity of Torres Villarroel's medical views to those of contemporary holistic medical reformers both suggest.

One of the most powerful characteristics of humoral/environmental ideas, seen in all the literatures discussed, is that they are constructed to make moral and political decisions seem empirical. These views consistently argue that the social structure or human behavior must follow a certain pattern because "nature" or "human nature" requires it to do so. The connection between analysis of the "natural" world and political and ethical conduct is made to appear direct and scientific.

In order to make this argument appear plausible, it is necessary that the natural world be both static and coherent. The humoral/environ- 


\section{I44 Complex Continuities}

mental world is one of fixed categories, of constitutions that tend toward harmony. The categories were created once and for all in the beginning and they cannot change. The "marvelous machine" runs on forever. Indeed, the problem of change in categories appears in the persistent conflict between the genealogical and environmental principles in these theories.

When Darwin succeeded in synthesizing the actions of the environmental and genealogical principles and showed that the continuing origin of species (natural categories) was an inescapable theoretical and empirical conclusion, he demolished the very foundation of humoral/environmental theories. With them also was demolished the apparently easy and obvious connection between natural categories and moral rules. The blow was so sharp and so surgically delivered that many of its implications have yet to be assimilated.

To a surprising extent, the static vision of the world on which the humoral/environmental scheme depended marches on, though it is maintained only at the cost of serious contradictions. Nor is it carried forward only by some fringe group of antiscientific thinkers. Many pre- and nonevolutionary ideas persist in the theoretical and empirical works of major contemporary scholars who consider themselves to be in the forefront of applications of evolutionary principles to the analysis of human behavior. The extent to which nonevolutionary elements invade the work of these scholars will, I hope, show clearly how much remains to be done before the Darwinian revolution can be considered complete. 


\section{CHAPTER 6}

\section{Human Sociobiology}

Given the scope of the polemic unleashed by human sociobiology in recent years, no one can enter this arena without some trepidation. It is a minefield because of the complexity of the biological questions involved and because application of powerful biological models to the study of human behavior simultaneously creates theoretical, political, and ethical difficulties. Precisely because this particular subject attracts so much attention, it is reasonable to believe that it touches directly on fundamental ways in which we conceptualize the relationship between nature and culture.

E. O. Wilson's Sociobiology: The New Synthesis (1975), a quasitextbook modeled in important ways on Darwin's Origin of Species, gave the field its public identity and set the boundaries of the current debate. That its sophistication in certain areas has been quickly surpassed is not an argument against its general significance. Such a book does not have a great impact simply because of the force of the ideas presented; they must be presented in an order and context that are themselves compelling. Sociobiology is a compelling work in this sense.

In On Human Nature (1978) Wilson attempts to address his critics 


\section{I46 | Complex Continuities}

and to expand the arguments advanced in Sociobiology. Wilson and Charles Lumsden's Genes, Mind, and Culture (Lumsden and Wilson I98I) attempts to specify the theoretical framework supposed to be implicit in On Human Nature. Though it makes certain points from the previous books clearer, it does not fundamentally alter the structure of Wilson's discourse on the relationship between nature and culture.

There is no doubt that sociobiology has an important contribution to make to evolutionary biology as a whole, no matter what the verdict about human sociobiology is. Ever since Darwin's Origin of Species there has been a recognized need for an evolutionary analysis of social behavior. Observations across wide ranges of species show that certain forms of self-sacrificing behavior are common in the animal world and are often advantageous to the fitness of the collectivity though they necessarily reduce the fitness of the sacrificing individuals. By evolutionary logic, such individuals would be less and less represented in populations over time, and this kind of collectively useful behavior would disappear.

Darwin himself was aware of this problem, as his statements on neuter and sterile groups within a species demonstrate. Solutions to it were not forthcoming. It resurfaced with considerable impact when V. C. Wynne-Edwards published his Animal Dispersion in Relation to Social Behaviour in I 962. He claimed that somehow individuals sacrificed themselves for the benefit of the group and he organized an array of evidence to support this view.

Wynne-Edwards' book was subjected to a detailed critique by G. C. Williams (1966), who found all of Wynne-Edwards' data wanting. In 1964 W D. Hamilton published the first of a series of papers that attempted to reconcile the individualism of selection with the preservation of certain behaviors beneficial to the group at the expense of the individual (Hamilton 1964, 1970, 1971a, 197Ib). This effort resulted in the creation of the concept of "inclusive fitness." Wilson succinctly renders it as "the sum of an individual's own fitness plus the sum of all the effects it causes to the related parts of the fitnesses of all its relatives" (Wilson I975: I I 8).

This seemingly simple concept accounts for the emergence of sociobiology. It argues that socially beneficial behavior can develop and be 
maintained in populations by evolutionary processes already understood, without need to invoke some vague notion of group selection. To the extent that certain behavior is beneficial to other members of the group closely related to the individual who exhibits such behavior, acts of self-sacrifice can make evolutionary sense. So long as the benefits that related group members derive exceed the costs to the individual, the behavior increases fitness.

To be sure, operationalization of this set of notions is extremely difficult. These practical problems have brought considerable refinement in the formulation of the arguments. But the fact remains that the concept of kin selection attempts to resolve a major problem that had blocked the application of evolutionary principles to the analysis of social behavior. Whether or not the idea must ultimately be reformulated, its importance cannot be questioned.

Application of sociobiological arguments to the study of humans, as well as to other social species, is not some diabolical ploy, the excesses of certain practitioners notwithstanding. This important new development in biological science is relevant to at least some social species and it is reasonable to entertain possible applications to humans. If arguments thus far advanced in regard to humans cannot be taken very seriously, they do not invalidate the enterprise.

No one should underestimate the harsh empirical requirements to be met in such an analysis. We need past and present population sizes; complete, accurate pedigrees; random mating system (unless the form of many sociobiological propositions is changed considerably); and typologies of "fitness-enhancing reciprocities," along with concrete data about their reproductive effects. While all evolutionary research involves empirical compromises that fall far short of perfection, compelling samples of data on these points are minimum requirements to be met before anyone can say that data exist to support or disprove the stronger sociobiological propositions as applied to humans. That such evidence has been less the center of attention than adaptive storytelling (pro and con) is part of the ambivalence surrounding sociobiology that needs to be unraveled.

The central question I ask of Wilson's work is whether or not he applies any particular element of specifically sociobiological theory to humans. The answer is no. Wilson's views on humans have not prof- 


\section{I48 | Complex Continuities}

ited from the intriguing propositions sociobiology could generate. What he says about humans was said not only before sociobiology came about but before evolutionary biology as a whole. Nor is this some personal peculiarity of Wilson's thought. In conceptualizing human nature, Wilson unknowingly reproduces a pre-evolutionary view of the relationship between nature and culture, thus failing to apply evolutionary analysis to human behavior and demonstrating the pervasive power of cultural systems.

Sociobiology: The New Synthesis

Morality, Selfishness, Altruism, and Kinship

Sociobiology's first chapter, "The Morality of the Gene," begins by taking issue with Albert Camus's statement that suicide is the only important philosophical question. It is the biologist, Wilson claims,

who is concerned with questions of physiology and evolutionary history, [who] realizes that self-knowledge is constrained and shaped by the emotional control centers in the hypothalamus and limbic system of the brain. These centers flood our consciousness with all the emotions ... that are consulted by ethical philosophers who wish to intuit the standards of good and evil. What ... made the hypothalamus and limbic system? They evolved by natural selection. ... This brings us to the central theoretical problem of sociobiology: how can altruism, which by definition reduces personal fitness, possibly evolve by natural selection? The answer is kinship. [Wilson 1975:3]

Then by a leap that has not worked for anyone, Wilson implies that understanding the material structure of the brain and the evolutionary process by which it came into being creates direct understanding of the content of human thought. We can adjudicate, he implies, between particular thoughts (in this case life versus suicide) by reference to biological structures and their evolution. This theme persists in his other works as well.

While the necessary material structure of the human brain does in an ultimate sense constrain what can be thought, these constraints 
relate so remotely to our ability to predict the content and structure of systems of ideas that Wilson's formulation cannot be taken seriously. Almost no one who accepts evolutionary theory will dispute the point that the hypothalmic and limbic systems evolved by natural selection or that we must learn why altruism is evolutionarily possible. But this knowledge will not automatically lead us to moral clarity.

Wilson's prose suggests that selfishness and altruism exist in a pitched battle, though nothing in the theory of inclusive fitness suggests that they must. He evokes an image of humanity torn between ambivalent impulses programmed into our brains and argues that understanding the conditions that led to this impasse will permit us to control our behavior. This is an optimistic view of the human condition with strong Freudian overtones. Nothing in it is entailed in the theory of inclusive fitness.

These very first paragraphs show something about Wilson's use of words that will compound confusion later on. "Morality," "selfishness," "altruism," and "kinship" are all words that directly imply a cultural capacity for abstract thought, for deliberative behavior. Wilson's use of terms taken from the cultural world humanizes the nonhuman world by imputing morality, selfishness, altruism, and kinship to cultureless creatures. Then by reverse extrapolation he applies these terms to humans. It then appears that we are just like all the other animals. This is just linguistic sleight-of-hand, a point Marshall Sahlins (1976) has made eloquently. That we are animals no one can doubt. That we are just like any other animal is less clear. We are biocultural animals-not nobler or better, but different.

\section{From Nature Through Mind to Culture}

These early pages set the baseline for Wilson's whole argument about the relationship between genes, mind, and culture. His reductive program for eliminating the distance between culture and biology operates by rhetorical means that have little or nothing to do with sociobiological theory proper. Even Wilson does not follow his reductionism: he holds "rationality" to be above the realm of direct biological causation, while making it crucial to our species' biological salvation. 


\section{I50 | Complex Continuities}

A highly social species such as man "knows," or more precisely it has been programmed to perform as if it knows, that its underlying genes will be proliferated maximally only if it orchestrates behavioral responses that bring into play an efficient mixture of personal survival, reproduction, and altruism. Consequently ... the conscious mind [is taxed] with ambivalences whenever the organisms encounter stressful situations. [P. 4]

The mind is simply a complex apparatus that overlies the genes and must necessarily act in the interest of perpetuating the genes of that organism. The mind is a fitness-informing device. In this way Wilson drives a wedge between the genes as an ultimate level of reality and the conscious mind as an environmental tracking device that calculates fitness outcomes of various courses of action.

Chapter 2 begins in a striking way with the following lines: "Genes, like Leibnitz's monads, have no windows; the higher properties of life are emergent" (p. 7). Here is an interesting conundrum. Much of the book argues that genetic causality is the only form of "real" biological causality. Yet here a combined argument for holism and emergent levels of organization is made the centerpiece. Wilson wants to use two incompatible views of the organization of the world as they suit his convenience.

Sociobiology is the study of the biological foundations of all social behavior. As genes underlie the mind, so sociobiology supposedly underlies sociology and the humanities. "It may not be too much to say that sociology and the other social sciences, as well as the humanities, are the last branches of biology waiting to be included in the Modern Synthesis" (p. 4). This remark threatens many territories and has been widely cited. Wilson claims to recognize no general causes of behavior that are not biological, and so the incorporation of the social sciences and humanities in the sociobiological synthesis will be accomplished according to the ground rules of biology. While this idea in itself is not bad, since nothing in the social sciences and humanities could in any ultimate sense conflict with the biological capacities of human beings, Wilson's terms of incorporation destroy rather than explain the social sciences and the humanities.

Wilson defines society as "a group of individuals belonging to the same species and organized in a cooperative manner" (p. 7). This 
vague and analytically useless definition of society is purposely broad, Wilson says, so that it can apply to almost any aggregation of a species in which some small degree of interaction occurs. In fact, this vagueness does not seem costly at the outset, but it becomes so when the similarities and differences in the social forms of different species and ultimately in human and other animal societies are examined.

Wilson provides an elaborate discussion of various mechanisms and effects related to the rate of the evolution of social behavior. He endeavors to develop a concept of "social drift," made up of a genetic element and a "tradition" element, in analogy to genetic drift. As an example of "tradition drift," defined as behaviors learned solely as a result of social experience, he speaks of the acceptance of a new idea in a human group. His model, which is a very old one, claims that ideas compete for acceptance, and the best variant survives. ${ }^{1}$

We can see here the weakness of Wilson's approach to cultural analysis. The mechanistic treatment of ideas apart from their content and contexts is inexcusable. Further, the modality for communicating ideas between parent and child and among cohorts is linguistic communication, a system of transmission dependent on distinctive cultural mechanisms. The acceptance or rejection of an idea is as significantly conditioned by its fit within a larger system of ideas and by the modes in which it is communicated as by any inherent strength or weakness in the idea itself.

Though the concept of tradition drift has something to recommend it, especially as applied to nonhuman animals (whose social learning has been underemphasized by scholars until recently), the application to humans reveals important weaknesses in Wilson's thinking. He abstracts out a prime characteristic of culture, but in the process he impoverishes the concept of culture beyond recognition. It is abundantly clear that he does not use the concept "symbol," "symbolic system," "context," or "meaning" in acceptable ways. These weaknesses ultimately ruin his discussion of humans.

Speaking of group size in an evolutionary context, Wilson uses the example of the Mennonites in the rural United States as proof that mechanisms found in other animal societies work for humans. This choice is quite revealing. Not only are the demographic data adduced very weak, but he forgets that the boundaries of Mennonite commu- 
nities are religiously defined. Yet the fluctuation he finds in Mennonite group size is said to represent the operation of universal mechanisms. How many macaque communities are bounded religiously and are ethnically oppressed? More important, Wilson's inclusion of the Mennonites does not enhance our understanding of them at all because it is already known that communal agricultural societies have an optimum size that varies according to changes in land base, technology, and communication. How does the use of evolutionary language improve our understanding of either the Mennonites or the macaques? If this is what Wilson means when he says that human behavior is "consistent" with sociobiological theory, then I see no difference between "weak" inferences and useless ones.

Wilson also misses opportunities to apply his models to humans well. When he discusses adjustable group size and describes societies that adjust their size to available resources, he does not mention humans. This is one subject on which there is somewhat better human evidence (Lee and De Vore, eds., I968). It appears that cultural systems are great facilitators of the expansion and contraction of group sizes and that kinship networks (in the correct anthropological sense of the term "kinship") serve to enhance the ability of groups to fuse and divide. Here, where a human example would be worth thinking about, Wilson overlooks the opportunity.

Later, after arguing that the correct definition of higher organisms is the degree of refinement in their ability to adjust to the environment (p. I5I), he takes up tradition once again. "The highest form of tradition ... is of course human culture. But culture aside from its involvement with language, which is truly unique, differs from animal tradition only in degree" (p. 168 ; emphasis mine). This statement is quite remarkable. Wilson uses a radical distinction here between humans and animals, yet presumably a major point of the book is to moderate just such a distinction.

The phrase "culture aside from its involvement with language" is incomprehensible. Ordinarily we define culture as a congeries of symbolically mediated behaviors that have some systematic internal organization. In the social sciences and the humanities we have often considered language a major paradigm for what culture in general is like. There is also wide agreement that the development of language 
is the key to the development of culture; that without one the other cannot exist. And finally, the absolute uniqueness of human language itself is being questioned by the very ethologists from whom Wilson otherwise draws so much sustenance. What, then, can Wilson mean? Unfortunately, the only interpretation that can be placed on this crucial passage is that Wilson does not know what he means by either "culture" or "language."

The chapters on communication support this contention. Though Wilson tries to use language as paradigmatic for communication systems (p. 177), he rejects the universal design features of language, is confused about phonemes, and entirely forgets that language is not analyzable without reference to meaning. And then, having used language as a paradigm for communication system in general, he reverses the field and argues that human language is unique (pp. 20I2) and that the application of human language concepts to other animal communication systems is risky.

In part, Wilson's problem is simply one of expertise. The material on aggression, spacing, and dominance is better handled. He retains a lively sense of multiple causes and multiple effects and he balances predictive statements with reasonable caution. Here he is clearly on familiar ground. Except for one careless aside on "obvious parallels" with humans in his discussion of the will to power (p. 287), this set of chapters, in which all sorts of bits and pieces of human evidence are fitted in, is not marred by the kind of outlandish comparisons that came earlier. Knowing this material better, Wilson is more diffident about extrapolation.

After a discussion of what he terms "role" and "caste" among nonhuman animals, Wilson turns to human roles.

But whereas, social organization in the insect colonies depends on programmed, altruistic behavior by an ergonomically optimal mix of castes, the welfare of human societies is based on trade-offs among individuals playing roles. When too many human beings enter one occupation, their personal cost-to-benefit ratios rise, and some individuals transfer to less crowded fields for selfish reasons. [P. $3^{\text {I }} 3$ ]

This statement could have been made by Galton, Malthus, or Milton Friedman. It reveals a naive free-competition model of society with- 


\section{I54 Complex Continuities}

out any awareness of problems of social stratification and power or of the long history of debate on this subject.

\section{Species Immortality}

Since modification of the environment is a particularly marked human characteristic, Wilson's comments on this subject have considerable importance.

Manipulation of the physical environment is the ultimate adaptation. If it were somehow brought to perfection, environmental control would insure the indefinite survival of the species, because the genetic structure could at last be matched precisely to favorable conditions and freed from the capricious emergencies that endanger its survival. No species has approached to environmental control, not even man. [Pp. 59-60; emphasis mine]

This statement needs to be remembered, for it contains the core of Wilson's peculiar utopianism. If we humans could manipulate the environment rather than letting it affect us, we could become our own ultimate causes in the world. And were we so inclined-as Wilson seems to be-we could try to bring evolution as we know it to a halt. This goal is nothing less than the achievement of species immortality in the material world. It is Wilson's alternative to the immortality of the individual soul.

Scholarly emphasis on human manipulation of the physical environment has led many authors to argue that culture has taken over from biology among humans. Wilson does not agree. He calls such manipulation an "adaptation," thus insisting that culture be treated as one more biological adaptation. While this position is generally reasonable, Wilson finds it necessary to ignore the symbolic and systemic aspects of culture.

Why does Wilson consistently ignore these aspects? I believe it is because he sees culture (in contrast with science) as obscuring our view of truth. Only when we purge culture of its irrational elements will culture give a true picture of the environment. Then we can reach the ultimate adaptation. Wilson thus wishes to reduce culture to its 
scientific-rational components. The rest of culture must be consigned to the dustbin.

\section{"Man: From Sociobiology to Sociology"}

Wilson has been repeatedly drubbed for his final chapter. Indeed, he published On Human Nature to remedy just this problem. But the errors in this chapter merit comment because they help to reveal the major cultural presuppositions that underlie Wilson's failure to apply evolutionary analysis to humans. All the difficulties discussed earlier now combine and interact.

The chapter begins with an invocation of an extraterrestrial zoologist, presumably because from an extraterrestrial perspective we humans could not deny that we are animals. Noting that we are ecologically "peculiar" because we are so wide ranging and locally dense in some areas, Wilson also stresses our anatomical uniqueness.

We have leaped forward in mental evolution in a way that continues to defy self-analysis. The mental bypertrophy has distorted even the most basic primate social qualities into nearly unrecognizable forms. Individual species of Old World monkeys and apes have notably plastic social organizations; man has extended the trend into a protean ethnicity. Monkeys and apes utilize behavioral scaling to adjust aggressive and sexual interactions; in man the scales have become multidimensional, culturally adjustable, and almost endlessly subtle. Bonding and the practices of reciprocal altruism are rudimentary in other primates; man has expanded them into great networks where individuals consciously alter roles from hour to hour as if changing masks. It is the task of comparative sociobiology to trace these and other human qualities as closely as possible back through time. Besides adding perspective and perhaps offering some sense of philosophical ease, the exercise will help to identify the behaviors and rules by which individual human beings increase their Darwinian fitness through the manipulation of society. In a phrase, we are searching for the human biogram. ... One of the key questions ... is to what extent the biogram represents an adaptation of modern cultural life and to what extent it is a phylogenetic vestige. Our civilizations were jerrybuilt around the biogram. How have they been influenced by it? Conversely, how much flexibility is there in the biogram, and in which parameters particularly? Experience with other animals indicates that when organs are hypertrophied, phy- 


\section{I56 Complex Continuities}

logeny is hard to reconstruct. This is the crux of the problem of the evolutionary analysis of human behavior. [P. 548; emphases mine]

There is much to consider here. "Hypertrophy" suggests an almost unnatural overgrowth of an organ. By what standards do we judge this condition? Do birds have hypertrophied digits? What is the difference between hypertrophy and a complex morphological adaptation? This is really an issue in classification. Wilson uses the term to suggest that humans may have gone too far in one direction and that we are much in need of perspective and self-control. As a biological concept in regard to humans, mental hypertrophy is vacuous.

At the same time that Wilson evokes human variability in ethnicity and in social roles, he darkly invokes a biogram that must necessarily set limits around the protean character of humanity. Biology teaches us, he suggests, what these limits are so we can know how to behave.

Surely this make no sense in view of his general theory. If, as he has insisted throughout the book, he is a biological determinist, then humans cannot behave in any way that is not biologically feasible. If this is the case, what is there to worry about? But Wilson is obviously worried. The true meaning of mental hypertrophy becomes clearer now. He thinks that overdevelopment of the brain can lead us to think and behave in ways that are not consistent with our survival. If we want to survive as a species, we must come back to reality and analyze the true evolutionary constraints that affect us.

Clearly this is a peculiar problem for an evolutionist to worry about. No other species concerns itself with species immortality. Species adapt or not; they continue or become extinct. For all his emphasis on evolution, Wilson finds such a fate intolerable for humanity. We should try to develop the perfect adaptation and become immortal as a species. While the appeal of this view is understandable, it has no conceivable connection to sociobiology and is only tenuously related to evolutionary biology. It is also a view that such thinkers as Malthus, Galton, Lorenz, and Desmond Morris have held without reference to sociobiological theory at all.

After this strange beginning, Wilson deals with human flexibility in more detail. He speaks of "ecological release" through lack of competition with other species (p. 550), and he christens the human ca- 
pacity for flexible behavior genetic "underprescription" (p. 559). This amounts to a double renaming of what most anthropologists would simply call cultural behavior.

Rudimentary discussions of language, the nuclear family, and other issues show how far out of his own area of expertise Wilson has strayed. These divagations should not be taken too seriously because the real point comes when Wilson tries to sharpen his analysis of culture.

"Culture, including the more resplendent manifestations of ritual and religion, can be interpreted as a hierarchical system of environmental tracking devices" (p. 560). Culture change and environmental change thus occur at similar rates. Religion, however, apparently interferes with such tracking:

Formal religion ... has many elements of magic but is focused on deeper, more tribally oriented beliefs. The enduring paradox of religion is that so much of its substance is demonstrably false, yet it remains a driving force in all societies. Men would rather believe than know, have the void as purpose, as Nietzsche said, than be void of purpose. ... The individual is prepared by the sacred rituals for supreme effort and selfsacrifice.... Deus vult was the rallying cry of the First Crusade. God wills it, but the summed Darwinian fitness of the tribe was the ultimate if unrecognized beneficiary. [P. 56I]

This situation is apparently connected to hypertrophy. Definable evolutionary conditions have led us to mental hypertrophy, which has increased our capacity for flexible behavior. But this flexibility is now hedged round by the irrationalism of religion, which has monopolized the means of indoctrinating people with regard to altruistic behavior. The "demonstrably false" religions are taking our hypertrophy and turning it into a danger for our species. This danger must be met, and the answer is sociobiology:

It seems that our autocatalytic social evolution has locked us onto a particular course which the early hominids still within us may not welcome. To maintain the species indefinitely we are compelled to drive toward total knowledge, right down to the level of the neuron and gene. When we have progressed enough to explain ourselves in these mechanistic terms, and the social sciences come to full flower, the result might be hard to accept. ... But we still have another hundred years. [P. 575; emphases mine] 


\section{I58 | Complex Continuities}

"To maintain the species indefinitely ... total knowledge." This is Wilson's true agenda. Our species should strive to maintain itself indefinitely by learning scientifically how evolution applies to us. Thus we must push aside religion and the other "cultural mystifications" that hide what we really are.

This is really an old call to the imposition of rational science over irrational religion on the promise of a utopian future. In this utopia the antithesis between nature and culture will have been abolished by science. The argument assumes that all that is truly human and worthwhile is rational, and that science is thus the quintessence of humanism (as against the false humanism of the so-called humanities). Surely this is the antithesis of the scientific method.

\section{Scientific Method and Loose Thinking}

One way of dealing with some of the most patent inconsistencies in Sociobiology is to claim that Wilson is simply a bad scientist, or at least a very naive one. Such a convenient view does not account for the data and is much too easy a way out of a complex problem. Wilson is a famous and widely respected scientist who clearly understands the canons of scientific method. His abstract discussion of the theoretical structure and requirements of sociobiology demonstrates this understanding. He emphasizes a distinction between ultimate and proximate causality, one that is now much bandied about. By "proximate causation" he means essentially such immediately functional causes as anatomy, physiology, and behavior. By "ultimate causation" he means the necessities created by the environment (p. 23). Clearly some such distinction is important in most dynamic analyses and in analyses where differences in scale are important. Yet these distinctions, unless they are carefully handled, are a perfect escape clause that can protect a theory from empirical challenge. If inconvenient evidence is found at one level, then causality at the other level can be invoked, and Wilson does invoke it repeatedly in his human examples.

In the section "Reasoning in Sociobiology" Wilson gives a fair characterization of the deductive basis of science. He discusses the use of "strong inference" and criticizes the "advocacy" method of proof. 
Arguing in favor of multicausal theories in sociobiology that move the various levels of analysis together in a sensible way, he concludes, "The goal of investigation should not be to advocate the simplest explanation, but rather to enumerate all of the possible explanations, improbable as well as likely, and then to devise tests to eliminate some of them" (p. 3o). One can only agree. This is a textbook scientific method. That Wilson is aware of these rules is important because, as we shall see, the requirement to develop a variety of hypotheses, devise tests, and apply them is dropped when his subject is humans.

By Chapter 5 he has moved far from these elegant statements about scientific method. Such comments as the following are found:

Human behavior abounds with reciprocal altruism consistent with genetic theory.... The critical gene frequency is simply that in which playing the game pays by virtue of a high enough probability of contacting another cooperator. The machinery for bringing the gene frequency up to the critical value must lie outside the game itself. It could be genetic drift in small populations ... or a concomitant of interdemic or kin selection favoring other aspects of altruism displayed by the cooperator genotypes. [Pp. I2O-2I]

The method of strong inference is gone, and with it the elaboration of multiple hypotheses and the use of tests to eliminate some. Proofs regarding human behavior in particular hang on the words "consistent with," a slippery phrase that says "caused by" without really defending or testing the proposition.

Wilson concludes Part I with the following statement:

Although the theory of group selection is still rudimentary, it has already provided insights into some of the least understood and most disturbing qualities of social behavior. Above all, it predicts ambivalence as a way of life in social creatures.... In the opening chapter of this book, I suggested that a science of sociobiology, if coupled with neurophysiology, might transform the insights of ancient religions into a precise account of the evolutionary origin of ethics and hence explain the reasons why we make certain moral choices instead of others at particular times. Whether such understanding will then produce the Rule remains to be seen. For the moment, perhaps it is enough to establish that a single strong thread does indeed run from the conduct of 
termite colonies and turkey brotherhoods to the social behavior of man.

[P. I 29; emphasis mine]

Wilson promises that sociobiology can convert religion and morality into science by reducing them to evolutionary theory. This moralized science promises to save humanity by purging culture of its irrational elements and bringing us into concert with the environment through reason. The scientific method and strong inference have been supplanted by the advocacy method. That a "single ... thread" runs from termites to man could be true in any typological system (e.g., we both locomote by means of limbs of some sort). The strength of his thread is supplied by the logic of the system he has created, not by any tests he devised or applied. The thread is strong only if we already believe Wilson.

\section{On Human Nature}

In writing On Human Nature Wilson had much damage to repair. The book is a great disappointment in this regard. It does, however, confirm my reading of the cultural system that underlies the views expressed in Sociobiology.

On Human Nature is an avowedly speculative view of the union of the natural and the social sciences. We shall see that the terms of union make it an annexation of the latter by the former. Not as compellingly organized as Sociobiology, it adopts a topical approach to aspects of human nature encapsulated in such chapter titles as "Dilemma" and "Hope." The body of the work contains a disappointing array of observations about humans.

Since the principles of both sociobiology in particular and evolutionary biology in general are suspended in the chapter on humans in Sociobiology, one approaches On Human Nature with hope that this failing will have been at least partly rectified. It has not. Indeed, its contents are indistinguishable from those of popular works by such authors as Lorenz, Ardrey, and Morris.

Sociobiology, given its important new formulations regarding the evolution of social behavior, should make some notable changes at 
least in the phrasing of evolutionary questions about human behavior. Yet one seeks in vain for new perspectives on human behavior in On Human Nature. The deviations from evolutionary analysis effectively domesticate sociobiology so that it preserves the traditional Western view of human nature while covering it with the terminological trappings of Darwinism.

\section{“Man's Ultimate Nature," Natural Reason, and Truth}

Chapter I opens with this question: "What is man's ultimate nature?" The question itself betrays the fundamental orientation of the work. What can the "ultimate nature" of a species mean if a species is a congeries of ranges of variation that are continuously shifting? Can we talk about the "ultimate nature" of a species in evolutionary biology? Certainly not. This concept only fits the chain-of-being model of creation. Thus the book begins on a nonevolutionary note.

This question is immediately followed by a statement that distracts our attention from the issues just raised and focuses on the specter of materialism: "If the brain is a machine of ten billion nerve cells and the mind can somehow be explained as the summed activity of a finite number of chemical and electrical reactions, boundaries limit the human prospect-we are biological and our souls cannot fly free" (Wilson 1978:I). This statement introduces a theme that runs throughout the work. Biology is a constraint on culture. To be realistic we must adjust our culture to this fact. Such a view of the relationship between biology and culture is inappropriate to modern biology, but it is common in the works of Hippocrates, Jean Bodin, and other pre-Darwinian writers.

Wilson has a strong tendency to link such concepts as soul with religion and culture, and to link such concepts as science and rationality with transcendence of the limits of culture. Wilson naturalizes reason: "The human mind is a device for survival and reproduction, and reason is just one of its various techniques"; "Human nature can be laid open as an object of fully empirical research, biology can be put to the service of liberal education, and our self-conception can be enormously and truthfully enriched" (p. 2). Reason is natural; natural science is about what is natural; what is natural is real and true. 


\section{I62 | Complex Continuities}

Thus natural science can tell us the truth about ourselves and move our reasoning onto a mature plane, far from the fantasy world of religion and the humanities.

In order to search for a new morality based upon a more truthful definition of man, it is necessary to look inward, to dissect the machinery of the mind and to retrace its evolutionary history. But that effort, I predict, will uncover a second dilemma, which is the choice that must be made among the ethical premises inherent in man's biological nature. [Pp. 4-5]

\section{Biological Constraints and Moral Choice}

According to Sociobiology, we are programmed for both selfishness and altruism. The only moral choice Wilson can understand is between these alternatives. In On Human Nature he eliminates this moral choice by arguing that it is rational to be altruistic. Further, he wants to use biology to prove that after we have measured the tightness of the material constraints, we still have the freedom to choose.

The challenge to science is to measure the tightness of the constraints caused by the programming, to find their source in the brain, and to decode their significance through the reconstruction of the evolutionary history of the mind.... [We will then be able to decide which] of the censors and motivators should be obeyed and which one might better be curtailed or sublimated. ... [P. 6]

This is an odd position for an author who begins a book with an epigraph from Hume, who compellingly portrays the distance separating "is" from "ought."

Wilson really only plays with the idea of constraint. He pretends to measure constraint to prove that we have the freedom to choose, that rationality has a role to play. Yet by annihilating the understanding of cultural systems in both of his books, he deprives that appeal to rationality of any context or meaning.

The question of constraint comes up again in a variety of forms: "The question is no longer whether human social behavior is genetically determined; it is to what extent" (p. I9). It is a serious error to attempt to analyze the relationship between biology and culture as a single continuum ranging from fully biological to fully cultural and 
then to place traits along the continuum. As Lewontin ([1974] 1976) has argued more powerfully than anyone else, this is bad biology.

All culture is biological, for without biological beings there is no culture. But if we agree that all culture is Ioo percent biological in this sense, we have said nothing useful about constraints, freedom, culture, or behavior. Wilson has simply restated the old dichotomies-environment/culture, nature/nurture, genes/culture, constraint/freedom. These polarities do not belong in evolutionary biology.

Wilson confuses the issue further: "Either possibility-complete cultural determination versus shared cultural and genetic determination of variability within the species-is compatible with the more general sociobiological view of human nature" (pp. 42-43). Having started from the position that everything humans do is biological and material, he here argues that some things may be cultural without being biological. This confusion is nothing more than an expression of the old dualistic model of human nature.

Wilson's quest for the ultimate nature of humans also leads him into trouble with biological diversity. He turns the problem over and over and finally tries the following formulation: "Hope and pride and not despair are the ultimate legacy of genetic diversity, because we are a single species, not two or more.... Mankind viewed over many generations shares a single human nature..." (p. 50). Whatever this statement means, and I challenge others to make sense of it, it only highlights the problem of trying to assert a species essence in the humoral/environmental sense and biological diversity in an evolutionary biological sense. The positions are irreconcilable.

At the end of the work, Wilson returns to the question of moral choice. Given our ambivalent "essence," we are biologically programmed to be free to choose between selfishness and altruism. But in his view, science tells us that only altruism is rational. As he puts it, "circularity of the human predicament is not so tight that it cannot be broken through an exercise of will." Sociobiology "will fashion a biology of ethics, which will make possible the selection of a more deeply understood and enduring code of moral values" (p. 196). Then he provides this biology of ethics:

Because natural selection has acted on the behavior of individuals who benefit themselves and their immediate relatives, human nature bends 


\section{r64 | Complex Continuities}

us to the imperatives of selfishness and tribalism. But a more detached view of the long-range course of evolution should allow us to see beyond the blind decision-making process of natural selection and to envision the history and future of our own genes against the background of the entire human species. A word already in use intuitively defines this view: nobility. Had the dinosaurs grasped the concept they might have survived. They might have been us. [P. I97]

This remarkable passage sums up Wilson's true agenda. The mental hypertrophy that characterizes humans should allow us to see past selfishness as shortsighted and to realize that altruism, though in the short term possibly disadvantageous, in the long term will ensure our survival. Evolution is blind but it has produced a creature capable of vision. Our will and our reason can permit us to outsmart the environment and approach the ideal of bringing evolution to a halt. We must look to empirical biological research for our ethical systems; we must derive "ought" directly from "is." The price for failure is ongoing evolution, which may leave us as extinct as the dinosaurs.

\section{Evolutionary "Truth"}

In Wilson's view, what most encumbers our vision is the "falsity" of our cultural systems. Our religious ideas are especially at fault because they supposedly deny the materiality of human life and celebrate the irrational. To address this problem Wilson suggests that we drop the "biblical epic" and put the "evolutionary epic" in its place.

The core of scientific materialism is the evolutionary epic. ... What I am suggesting ... is that the evolutionary epic is probably the best myth we will ever have. It can be adjusted until it comes as close to truth as the human mind is constructed to judge the truth. And if that is the case, the mythopoeic requirements of the mind must somehow be met by scientific materialism so as to reinvest our superb energies. [P. 20I]

Man's destiny is to know, if only because societies with knowledge culturally dominate societies that lack it. [P. 207]

The problem is that our cultural knowledge thus far in human history has been "false." Now we can make it "true." 
What is the truth? It appears that the truth is that a judicious combination of selfishness and altruism is the only evolutionary strategy that will work. This is universally true no matter what the circumstances or time period. Under these conditions, the only moral thing to do is to follow the dictates of scientific reasoning, which has uncovered the universal and eternally best strategy for survival. Thus Wilson ends by spiritualizing biological science, trying to convert its results into direct guidelines for behavior based on the analysis of the diversity of species now existing and their evolutionary histories.

\section{Genes, Mind, and Culture}

In collaboration with the physicist Charles Lumsden, Wilson has made yet another attempt to deal with humans in a way that is supposed to be sociobiological. To Wilson's credit, he not only keeps trying to strengthen his position but also recognizes basically where the difficulties in the enterprise lie. The relationship of the genetic, mental, and cultural components of human behavior has been the central difficulty, and Genes, Mind, and Culture (Lumsden and Wilson I98I) deals directly with this problem.

As in the case of On Human Nature, one reads this book in the hope that the enormous amount of criticism leveled at Wilson's two earlier works will have significantly sharpened his formulation. Despite an improved lexicon, a complex statistical apparatus, and wider reading in cultural anthropology, Wilson has become so entangled in the difficulties already described that he has moved away from rather than toward his goal.

In the Preface Lumsden and Wilson argue that genetic and cultural evolution must be linked, and that the connection between them may be found in "the ontogenetic development of mental activity and behavior" (Lumsden and Wilson $198 \mathrm{r}$ :ix). This argument is coupled with a criticism of sociobiology for having failed to deal successfully with the operations of the human mind and with the immense amount of cultural diversity found even in the contemporary human world. This is an encouraging beginning.

The Introduction contains virtually unexceptionable statements about 


\section{I66 | Complex Continuities}

the necessary relationship between genes and culture: "We view it . . . as a largely unknown evolutionary process-a complicated, fascinating interaction in which culture is generated and shaped by biological imperatives while biological traits are simultaneously altered by genetic evolution in response to cultural innovation" (p. I).

Except for the use of the indefensible term "cultural evolution" (a fault the authors share with most other practitioners in this field), ${ }^{2}$ this reasoning makes sense. No doubt there must be a relationship between genes and culture. Conceptualizing it as a complex, interactive process seems currently the most promising way to move the discussion. Yet within a few pages the authors manage to extinguish all enthusiasm for their approach by returning to the contradictions that flawed Wilson's previous works.

Early on we are faced with the possibility of "pure cultural evolution," which is somehow dependent on genetic controls. The conceptualization of the relationship between genes and culture is as confused as ever. Once again Wilson views the relationship between genes and culture as one in which genes hold culture "on a leash" (now called the "leash principle" [p. I3]). Most of the book is devoted to mathematical estimates of the varying length of the leash.

Without genes there is no culture. Yet genes hold culture on a leash. The incompatibility of these two views is clear. If we argue, as we must, that without genes there is no culture, then the only reasonable idiom for discussing the relationship between genes and culture is one involving the analysis of the relationship between levels of causation, perhaps in the general systems mode. But if we follow this course, it makes no sense to say that genes hold culture on a leash. The leash principle asserts that there is one entity in the world to be called "genes" and another to be called "culture," and that the degree to which the former ordains the details of the latter is determined by the length of the leash between them. The leash principle reproduces the old nature/culture argument while the idea that there is no culture without genes demolishes the distinction.

Because this approach is deeply wound into the internal structure of the work, it compromises the rest of Genes, Mind, and Culture. Culture is treated as an adaptive system without reference to the problem of meaning. The mind remains a fitness-informing device 
concerned with survival and reproduction; and evolution is again treated as a myth that is powerful only because it is "true."

Wilson still recoils from the notion that the apparent complexity of human sociocultural arrangements must be taken seriously rather than reduced to a few homilistic rules. "Although Homo sapiens is the most complex species on earth by a spectacular margin, it is probably far less complex and difficult to understand than contemporary social theory leads one to believe" (p. 350).

He then takes aim at hermeneutics as a kind of obscurantist philosophy designed to descend into an antiscientific universe of cultural details. He tips his hat to Marx's attempt to formulate the laws of history, saying that the effort was a good one that now can be carried forward with the help of sociobiology. And the book closes roughly where Sociobiology closed, all the evocations of interactive biocultural processes and of cultural complexity having produced no substantial effect. No more convincing display of the power of culture to invoke and maintain meanings can be found than Wilson's own derailment of evolutionary biology in the service of his nonevolutionary view of the relationship between nature and culture.

\section{Wilson as an Evolutionist}

It is clear that when Wilson deals with humans, he uses neither sociobiology nor evolutionism. Rather he is a naturalistic thinker in the tradition of those whose ideas rest on a dichotomous static vision of nature and culture. Except for the occasional loose connection made between kin selection, reciprocal altruism, and cooperative behavior, Wilson is content to use biological information to make the case that we humans are in grave danger of extinguishing ourselves because of the contradictions in our "nature."

Most of the major rules of evolutionary biology are overturned. Despite some remarks here and there about diversity in human populations, Wilson speaks of humans as having a "nature," indeed as having an "ultimate nature" that is potentially permanent. Nothing in evolutionism permits such assertions. A species is an interbreeding 
congeries of varying traits, continually in motion, with fuzzy boundaries in fact, if not by definition.

Wilson's goal is to preserve our species from extinction by perfecting our ecological release via proper balancing of our selfish and altruistic natures. While the goal of preservation of our species may be laudable, nothing in evolutionary biology justifies such actions. Evolutionary biology is not about preserving species indefinitely; it is about the mechanisms and trajectories of evolutionary change.

In the most bald fashion, Wilson repeatedly moves from what he considers to be the facts of evolutionary biology to the moral imperatives he thinks we must follow. He leaps across the boundary from "is" to "ought" without regard for most thinkers' belief that such a leap is rationally unjustifiable and ideologically compromised. He thinks that a philosophy of empiricism will simply and directly solve our moral dilemmas.

This belief finds no support in evolutionary biology. Evolution is a theory, not a description of neutral facts. Evolutionary theory produces no clear moral imperatives. We may weigh the evolutionary consequences that can arise from various courses of action, but the choice of a course of action and the imposition of that choice on others in our society cannot be justified on simple evolutionary grounds.

Wilson's pattern of thought is not explicable in terms of evolutionary theory but it does fit the old Western view of the human epic. Humans began in a state of nature in which natural laws virtually controlled all. As we became increasingly successful and proliferated, our cultural ideas became more and more complex, obscuring the "real" (natural) requirements of human existence. We began to act in ways not in our collective interest. But this dangerous cultural world also gave rise to the scientific method, and its advance ushered in the possiblity of a final age of human evolution in which scientific purging of untrue cultural ideas will permit us self-consciously (rationally) to regulate our relationships with nature, using reason to abolish the contradiction between nature and culture. This is an elite-managed rational utopia.

While a knowledge of evolutionary biology does not help us understand what Wilson thinks, an understanding of medieval theories about the relationship between purity of blood and social order does. The 
genealogical principle dominates in those theories, and blood "holds culture on a leash"; the social order is a reflection of the biological characteristics of the population. Environmental and historical effects, such as invasions and migrations, have confused the relations between blood and social position. As a result, a scientific analytical effort is necessary for effective political management and responsible moral judgment.

Social order depends on obedience to these basic "natural" principles. "Science" served this medieval enterprise in the form of elaborate genealogical investigations to determine the "natural" constraints involved. Politics and ethics were felt to be the direct expressions of rational inquiry. History was viewed as the playing out of these natural principles. Once the principles were understood, history became an intelligible, manageable process.

The claim that Wilson's construal of the relationship between nature and culture has much in common with arguments about purity of blood is not made with the intention of ridiculing Wilson. He is a sincere and serious scholar and deserves to be treated as such. Rather it emphasizes the fundamental similarity between his views and those pre-evolutionary views in reifying the distinction between nature and culture as a way of harnessing science to political and moral judgment.

What then is sociobiological or evolutionary about Wilson's view of humans? Nothing. Wilson's human sociobiology has been fully domesticated by an ancient Western cultural vision. That his own view of human nature cannot explain analytically the power and permanence of the very cultural visions of which he is captive is the strongest reason to reject what he says.

Lest it be thought that Wilson is singled out for particular abuse, I must point out that Wilson's opponents often argue in ways that differ little from his. As is commonplace in attacks on biological determinist views such as Wilson's, some opponents take such extreme counterpositions that they end up arguing from supposed "facts of nature" to their own particular political and ethical preferences.

One of many egregious examples in the antisociobiological literature is the Sociobiology Study Group's “Sociobiology: A New Biological Determinism" (I977). After offering theoretical and empirical 
criticisms of Wilson's views-all perfectly legitimate and powerfulthey argue that there can be no evidence for sociobiology because "the truth is that the individual's social activity is to be understood only by first understanding social institutions ... we know of no relevent [sic] constraints placed on social processes by human biology" (p. I48; emphasis mine). This mode of argument mirrors Wilson's advocacy view. The Sociobiology Study Group's "scientific facts” about humans are turned into direct support for their own political and ethical scheme. This logic is as unacceptable in the Sociobiology Study Group as it is in Wilson. Both sides are guilty of attempting to create the illusion that science supports their politics and ethics.

Does this mean that human sociobiology is an enterprise devoid of merit? The very criticisms I have made force rejection of this claim. Since Wilson's approach to humans is nonevolutionary, a rejection of Wilson does not entitle us to reject human sociobiology. Whatever the possibilities of human sociobiology are, Wilson does not explore them in an evolutionary way. Thus my argument is not about the truth or falsity of human sociobiology; it is an explanation of the cultural forces at work that have led a major evolutionary biologist to reject much of the evolutionary paradigm when he deals with humans, that have made many of his critics equally antievolutionary, and that have led both to resemble medieval thinkers theorizing about the relationship between blood and social order. The genealogical principle, the environmental principle, and the static categories of species in the world, albeit in modified form, are still powerfully present, along with their political and moral accompaniments. 


\section{CHAPTER 7}

\section{Cultural Materialism}

It is tempting to dismiss Wilson's reliance on theoretical and ideological structures familiar to us from pre- and nonevolutionary thought as a peculiarity of his own thinking. But Wilson's difficulties are shared in the human sociobiological writings of Richard Alexander (1979), David Barash (1979), and Richard Dawkins (1976), among others. The problem, of course, could be a peculiarity of sociobiology, irrelevant to other attempts to apply evolutionary theory to the study of humans. An analysis of Marvin Harris' "cultural materialism," however, shows the problem to be much broader. In Harris' presumed application of evolutionary ecology's energy-flow analysis to certain human cases, the same flaws are evident.

Sociobiology and evolutionary ecology are quite distinctive theoretical structures within evolutionary biology. Though they must ultimately be reconciled under the overall principles of evolutionary biology, they focus attention on quite different aspects of biological systems and use very divergent methodologies. Were cultural materialism and human sociobiology genuine applications of these theories and methods, they should be quite distinctive. Yet Harris' and Wilson's works 


\section{2

share many of the same defects. Their similar difficulties arise not from evolutionary biology but from both authors' reproduction of key elements of pre-evolutionary naturalistic views of society in their work, in particular their common commitments to static "natural" categories and the nature/nurture dichotomy, and to deriving political and moral conclusions from the study of "nature."

\section{Cultural Materialism}

The application of frameworks based on the analysis of population/ resource relationships to human situations antedates modern evolutionary biology. It is conventional, though not therefore correct, to claim that Malthus made the first scientific statement of this approach in 1798 . The recent popularity of population/resource models and theories dates from the I 960 s and is associated with Paul Erlich, Barry Commoner, Garret Hardin, "Earth Day," the Club of Rome-that is, the ecology movement. Spokespersons for this perspective share the common aim of using ecological analysis as a basis for the formulation of social policies.

Despite some intriguing proposals, none of these scholars and groups really came to terms with the cross-cultural application of ecological perspectives. Certainly none of them dealt effectively with cultural diversity or the full sweep of human history. Into this gap stepped the anthropologist Marvin Harris.

Harris began these efforts in 1974 by reanalyzing some of the major problems in the interpretation of human diversity and history with the aid of ecological perspectives. He calls his approach "cultural materialism" to set it off from other ecological approaches. Cultural materialism first was brought to the attention of the general public in two very popular books-Cows, Pigs, Wars, and Witches ([1974] 1975) and Cannibals and Kings (1977)-which projected Harris into the arena of both academic and public debate.

Harris, who does not shrink from criticizing opponents, has polarized his sympathizers and detractors and now stands at the center of a series of polemics that are always revealing, occasionally entertaining, and often fruitless. Indeed, because of this polemical atmosphere, 
people who analyze the role of ecological analysis in anthropology are tempted not to deal with Harris. His treatment of critics is both unpleasant and unproductive. Neither he nor his supporters have shown much willingness to learn from criticism.

Harris is nevertheless important. Most generally unbiased readers of his popular books are readily convinced by his arguments and react with considerable hostility to criticism of his work, seeing criticism as an attack on science, rationality, and the experimental method. Harris' detractors, on the other side, are always mystified by the power of his seemingly weak arguments.

For this reason Harris must be taken seriously. He has an uncanny ability to capture the imagination and scientific optimism of an audience through arguments for the application of ecological principles to the analysis of human problems. Yet Harris violates evolutionary reasoning at every turn, shows little awareness of the evolutionary ecology that he claims to employ, and appeals to his audience mainly through just-so stories about adaptation, rationality, science, and democracy.

Harris returns to important aspects of the pre-evolutionary Western view of the relationship between nature and culture, and he does so by violating most of the principles of science, rational argument, and the experimental method to which he appeals. Anyone who wants to see useful applications of a balanced combination of evolutionary biology and cultural analysis to human beings has first to deal with Harris' claims.

Harris' history as an anthropologist extends back to monographs on race relations in Brazil and in Mozambique. The part of his work relevant to the persistence of nonevolutionary views in the study of humans begins with the publication of The Nature of Cultural Things in 1964 . This book is a methodological essay on the "objective" observation of human behavior. It was followed in 1968 by his monumental Rise of Anthropological Theory, in which he rewrote the history of anthropology to legitimate the development of what he came to call "cultural materialism." In I97 I he published a very successful introductory textbook, Culture, Man, and Nature, in which the principles of cultural materialism were put into play for teaching purposes. Revised versions of the book are still in print. These works 


\section{I74 | Complex Continuities}

were followed by the four books I shall examine here: Cows, Pigs, Wars, and Witches; Cannibals and Kings; Cultural Materialism; and America Now. The first of these books is his attempt to explain strange cultural behaviors by cultural-materialist means; the second endeavors to make the cultural-materialist model dynamic; the third is a theoretical defense of cultural materialism and an all-out attack on its opponents; and the fourth is an interpretation of the ills of American society.

\section{Cows, Pigs, Wars, and Witches}

Originally published in 1974, Cows, Pigs, Wars, and Witches is a gem that rewards close reading. Tightly structured, lively, and occasionally both eloquent and convincing, it reveals a pattern of thinking that remains consistent throughout Harris' subsequent works. Here Harris throws down the gauntlet, claiming that he can explain with his method what the rest of us recognize as problems but are unable to deal with. He asserts that science is on his side, a bold claim in a bold book.

\section{Objectivity and Science vs. "Cultural Dreamwork"}

Harris opens with the statement that theory must reflect the "real" world (p. vii). Though hardly revolutionary, it immediately raises the question of what kind of "real" world he believes is out there. It will become clear that his theoretical preferences favor a view of the real world as a realm that operates in accordance with a very small number of "natural" laws. The real world for Marvin Harris is a world of energy flows. Calories and the ecosystems through which they flow are the material reality of human life to which he believes a true cultural science must refer.

Harris evokes the antiscience ideology of the I960s, specifically the arguments that rationality in general and science in particular are the prime causes of our social problems. Whenever this antiscience specter is raised, Harris waxes furious and occasionally compelling. A staunch defender of science, Harris argues that whatever the causes of our problems are, too much scientific understanding of the causes 
of social life is not one of them. One can only agree with him in general and with his assertion that much more study of the material organization of the human world is vitally necessary.

But Harris' own argument goes far beyond the demand for more scientific work. He insists that the testing ground for a science of human behavior must be a coherent scientific (and therefore materialistic) explanation of the highly various, puzzling lifestyles that anthropologists have often portrayed so engagingly. The subtitle of this book, The Riddles of Culture, refers to cultural practices that have generally defied anthropological analysis (according to Harris). He claims to resolve these analytical problems with his theory, thus giving a scientific explanation to culture.

Despite the scope of the task, his argument is very simple: "I shall show that even the most bizarre-seeming beliefs and practices turn out on closer inspection to be based on ordinary, banal, one might say 'vulgar' conditions, needs, and activities" (p. 5). The problem is that

practical life wears many disguises. Each lifestyle comes wrapped in myths and legends that draw attention to impractical or supernatural conditions. These wrappings give people a social identity and a sense of social purpose, but they conceal the naked truths of social life. Deceptions about the mundane causes of culture weigh upon ordinary consciousness like layered sheets of lead. [Harris [1974] 1975:5; emphases mine]

The call is to strip off the disguises, to reveal our self-deceptions by means of science.

Certain words and turns of phrase are most informative. Practical life is "disguised" in a costume created by a "wrapping" of myth and legend. The meanings people create, then, are external to the major causes of human existence. These disguises provide interpretations of experiences, but they are at base "deceptions" that cover the "naked truths of social life." In a few lines Harris has separated our material life as humans from the meanings we attribute to it. He has equated cultural interpretations of the "naked truths" with disguises and deceptions. Cultural systems of meaning are for him intrinsically false "layered sheets of lead."

The necessary implication is that Harris' own consciousness is in 
some sense not culturally mediated; that it is not "ordinary." If he can see the "naked truths" for what they are, his sources of conceptual objectivity must be uniquely noncultural. This is, in effect, his definition of science-the use of nonculturally mediated objectivity to strip the disguise from the naked truths of social life. His views are remarkably like E. O. Wilson's.

Harris takes up recognized major problems of anthropological interpretation to "test" his approach and to "prove" its validity. $\mathrm{He}$ deals with Hindu sacred cows, Melanesian pig veneration, Middle Eastern pork prohibitions, primitive war, male aggression, the potlatch, cargo cults, religious movements, and European witchcraft. Each case is treated as a challenge, a riddle to be solved.

Harris seeks to ferret out the underlying material causes of these apparently irrational phenomena to find the unitary truth behind the disguise. He is generally a pleasure to read as he goes about his task. The analysis is always interesting and occasionally genuinely provocative. There is no lack of intellectual derring-do and fun. Harris must be read to be appreciated.

\section{Taboos against Temptation as Inferior Science}

Harris' type case is the sacred cow of Hinduism. "Sacred cow" has become a Western cover term to refer to all that is irrational in cultures different from our own. Harris argues that Hindu cow veneration is based on sound ecological principles. Specifically he argues that by making the cows sacred, the Hindus conserve an ecological balance and population density that would otherwise be impossible to maintain. He is able to adduce some limited energetic evidence to support his argument. There is no doubt that Harris considerably altered our way of thinking about sacred cows; his formulation has forced researchers to take this phenomenon more seriously than they had done before. This alone is sufficient recommendation for Harris' argument, but my interest here is in the larger logic of his position and his general methodology as well.

After the sacred cows are disposed of, Harris moves on to other cultural practices for which he provides a cultural-materialist explanation. In comparing places where pigs are venerated with places where 
they are abominated, Harris rejects the "cultural" interpretations of these phenomena out of hand. Once again he equates the "natural" with the mundane and material and implies that culture is the opposite: unnatural, vague, spiritual (real nature versus unreal culture). He does sympathize a bit with Maimonides' medical materialism because it deals with the natural, definite, mundane forces that are involved in everyday life (p. 40). But Maimonides was too narrow for Harris; he did not include the whole ecosystem of which human behaviors in relation to pigs are a small part.

Given the desert environment of the Near East, Harris argues that pig prohibitions are good ecological practice. But apparently good ecological strategy alone is not enough for "pre-scientific" people, for "as in the case of the beef-eating taboo, the greater the temptation [here to raise pigs], the greater the need for divine interdiction" ( $p$. 44). Thus people have to create elaborate false explanations to support their correct ecological strategies. This is the only way to avoid the temptation of destroying the ecological basis of their societies.

Just why people are tempted to do something wrong that the gods must protect against is not clear. If evolution is the guiding force in human behavior, why do people not simply behave as they must without any cultural "dreamwork"? Harris' answer apparently is that, in the absence of modern science, these ecological forces cannot be understood directly. Hidden in his apparent respect for the practices of other cultures is a unilineal argument for the development of objectivity and science, a view that has been immensely popular in the Western world for a long time. The Western world is placed at the pinnacle of rationality.

But if uniform material causes have uniform effects (as science insists), we are within our rights to ask what are the practical, natural, mundane forces that obligate Harris to seek this form of objectivity and that cause him to wrap social reality in science. His answer is that science is objective and that he is a scientist. So despite the fanfare, his argument ends up restating, though with some new twists, the contrast between the cultural orientations of primitive societies and modern ones. He believes that the full potential of modern society has not yet been realized and that its realization requires the intercession of scientific intellectuals. This is hardly a new idea. 
When Harris deals with primitive warfare, his lack of regard for people's own conceptualizations of their lives and motives becomes even clearer.

Irrational and inscrutable motives predominate in current explanations of primitive warfare. Since war has deadly consequences for its participants, it seems presumptuous to doubt that the combatants know why they are fighting. ... But ... the answers to our riddles do not lie within the participants' consciousness. The belligerents themselves seldom grasp the systemic causes and consequences of their battles ... [P. 62]

People have motives for what they do but they are incapable of understanding the real reasons for their actions. These reasons are systemic, not individual or motivational. Only true scientists can comprehend systemic causes and consequences.

This position is rather awkward. Harris argues that people must have a structure of culturally created motivations that encourage them to behave as they must for the sake of their system, but their set of motivations never represents the system as it really is. To see the "real" system, an outside scientist is required. But by what evolutionary path can people end up incapable of understanding the "real" causes and consequences of their behavior? Surely people in other cultures are not less intelligent than we are.

\section{Ecosystem Analysis}

Harris claims that the key to all these problems is ecosystem theory, especially energy-flow analysis. He wants to show that all such behaviors are part of ecological adaptive strategies that yield the best possible results in their context. By applying these "material" principles to the analysis of unusual human behaviors, Harris tries to solve cultural riddles.

Does ecosystem analysis support him? The kind of ecological theory and the ecological data he uses are exceptionally primitive. The sacred cow argument is perhaps the one for which he has the best empirical evidence.

The portraits of the Indian ecosystem (pp. 16-19, 22) and of the 
others Harris discusses do not approximate any ecological standard. They are evocations of whole environments, incredibly diverse areas with enormous diversity of interlinked ecosystems. While there is no question that India, even the planet Earth, can be called an ecosystem, there is a real question whether this level of abstraction is relevant to a behavioral analysis such as the one Harris tries to make. Harris' argument centers on fine adjustment mechanisms in local ecosystems in which cows play a particular role. Yet as his portrait of the ecosystem is virtually India-wide, it is necessarily vague and abstract.

At the level of local detail, even ecologists who deal with relatively simple ecosystems find it necessary to devote hundreds of pages to the microenvironmental diversity and complex dynamics of an ecosystem before a small sample of the activities of humans can even be factored in (Netting I971, E. Smith 1980, Winterhalder 1977). Thus Harris does not really apply ecological analysis to the Indian environment; rather he evokes the material world and then goes on.

Unfortunately this is true of all of Harris' cultural-materialist works, though as a matter of theoretical conviction he argues persuasively for the study of the specificities of the material interactions between humans and our environments. As he offers neither careful operationalization of concepts nor empirical proof, however, his argument can appeal only to those who are already convinced. While his audience is large and enthusiastic, the fact remains that Harris uses an advocacy method of argument when he deals with the human condition. This is not a scientific strategy.

\section{The Sources of Scientific Objectivity}

The question of objectivity is particularly vexing. In the analysis of sacred cows, for example, Harris squares off against Alan Heston, who has argued that the cows perform important ecological functions but that India would be better off with fewer of them. Harris counters that Heston's program would lead to the elimination of small farmers and the improvement of the lot of the larger farmers. Harris is certainly right to consider the distributive effects of development policies, but the difference between the two scholars opens up an interesting question. If Harris' cultural materialism is supposed to explain 
the sources of cultural ideas, then where do Heston's false ideas come from? And what is the source of Harris' correct ones?

Though Harris provides no clear answer in abstract terms, his explanation can be derived from the overall structure of his analysis. The Indian farmers' ideas arise from the cultural "dreamwork" that wraps and hides the "naked truths of social life." The penalty for thinking other than the way they do would be mass starvation. This much is consistent with Harris' cultural materialism.

In capitalist societies, and especially in the ranks of academe, people are capable to thinking up ideas and rules for behavior that are completely at odds with the "real" world. How they can do so in a world that, according to Harris, is uniformly ruled by material causes is a real problem for his theory. His answer appears to be that a shortlived bubble of capitalist abundance has somehow unhooked us from the real world. This is a major part of the argument in Cannibals and Kings. It appears that uniform material causalities argued for in Harris' cultural materialism are not so uniform after all.

\section{Riddles that Dissolve into Social History}

Harris' argument contains a source of slippage that effectively demolishes most of his own theoretical claims. At one point he says: "This is an appropriate moment to deny the claim that all religiously sanctioned food practices have ecological explanations. Taboos also have social functions" (p. 45). Though not particularly debilitating in this context, this point comes up repeatedly in his work. While Harris insists on the universal applicability of his materialist arguments, whenever he runs into trouble he invokes a social or historical factor to explain the anomaly. This strategy effectively insulates his theory against any negative evidence, much as does Wilson's use of proximate and ultimate causality. So much for science.

In dealing with primitive peoples Harris introduces historical forms of explanation in a most disturbing way. Attempting to explain anomalies in the behavior of the Yanomamo Indians of Venezuela, Harris argues that their recent movement into their geographical area and adoption of a new subsistence system accounts for many of their problems. He speculates that they had been a nomadic people and 
began only recently to experiment with agriculture. The resulting great food increase led to higher population densities, which in turn created problems with hunting and other activities. The Yanomamo "have already degraded the carrying capacity for their habitat" (p. I05).

But how are such processes possible in the framework of his theory? How can the "adaptedness" of one system be compared with another? How can the degree to which a particular society meets a set of analytical expectations or deviates from them be measured? Without having answered these questions, Harris deviates from direct costbenefit optimization in the analysis of particular behaviors or groups of them whenever it suits his convenience to do so.

This is not a side issue. If we follow Harris' approach to the analysis of a particular society, we must know whether or not the society has been in its present location long enough to have worked out a well-balanced adaptation to the environment. Such knowledge requires some useful measure of "adaptedness." Neither of these requirements is met. Any time the data do not fit his expectations well, the lack of such knowledge constitutes an open invitation to consider that the cause is historical, that the deviation is caused by some interference. But the deviation could also be caused by bad data, poor formulation of the analytical categories, or simply an incorrect analysis of the data.

An evolutionary ecologist, recognizing that these issues have to be fully settled by agreed-upon measurements, would see this requirement as a heavy additional weight on an analytical framework that is already difficult to apply because it makes extraordinarily comprehensive empirical demands. Harris does not face up to this problem. His approach is to tell just-so stories about adaptation without much interference from the data. Lacking good ecological data, the formulation of alternative hypotheses, consistent analytical standards, and operational tests, Harris' view becomes a textbook case of adaptationism.

Examples of this approach are found throughout the book. Harris argues that the potlatch of the Kwakiutl functioned as a necessary redistribution of resources; that is, it was a systematic process. Why did the Kwakiutl have such a system when the Yanomamo do not? Harris would probably answer that the Kwakiutl had been in their 


\section{I82 | Complex Continuities}

environment longer and had worked out their adaptation fully. But what theory of evolutionary ecology tells us how long it takes to become "adapted"?

While it makes sense to argue that societies that have taken up a new way of dealing with the environment relatively recently will be less finely tuned to the local ecology than those that have been in place longer, such an argument must meet high theoretical standards. Among other things, there must be a set of definite criteria by which to judge the "adaptedness" of societies. Further, it is necessary to model the adaptedness of a society over time and predict how long is long enough for stable adaptations to develop in particular ecological zones given certain sets of food-getting strategies.

This line of reasoning also implies that some kinds of societies degrade their environments and others do not. The theory must explain under what circumstances a society does and does not produce a stable adaptation. Harris opens the door to all of these dilemmas the moment he abandons direct material causation by invoking a loose historical standard for judging adaptations.

The alternative is even worse. To argue, despite the existing evidence, that all societies are well adapted to their ecosystems would be a travesty. But to save the argument by shunting the deviations from expected adaptations off to history is no solution. Harris' next book, Cannibals and Kings, attempts to solve just this problem.

As the reader is brought to consider messiahs and the witch panic in Europe, the problems of historical causality get worse. Harris uses these cases to try to explain how consciousness got so far out of touch with "reality" in Western societies. His strategy obligates him to explain why the panic broke out when it did and not earlier or later. This sort of question plagues all historians and is not helped a bit by Harris' cultural materialism.

Harris seeks demographic and ecological causes for these events, but his arguments rest on such a long series of assumed relationships that they are of little interest to anyone familiar with the details of the great religious upheavals in Europe and the United States. If Harris only wanted to persuade us to pay close attention to the material aspects of social life during the period of these outbreaks, no one could disagree. But he sacrifices the analysis of the detailed social 
etiology of these movements in order to make room for his particular materialist interpretation, which then turns out to be too vague to be helpful.

\section{"The Return of the Witch"}

As he begins to close out the argument, he speaks metaphorically of the "return of the witch," meaning the ways in which contemporary consciousness is out of touch with "practical and mundane constraints" (p. 252). How can consciousness, which is, in Harris' own words, "adapted to the practical and mundane conditions" (p. 253), get out of touch with those conditions? No answer is given.

The reader is left with the idea that primitives think about what is in fantastic symbols while peasants and academics think about what is not in other kinds of fantastic symbols. Only scientists, and in particular cultural materialists, relate "true" consciousness to the practical and mundane constraints of everyday life. Marvin Harris believes that we must use science to learn to eliminate from our culture all of our false conceptions of how things are and ought to be.

Harris' drive for data about the material world is good, a useful corrective to anthropology's large dose of idealist bias and empirical laziness. His inclusion of the Western world in anthropological comparative statements is important and his flashes of insight and wit are engaging. Still the book is a great disappointment. Ecology is invoked only in the loose sense that everything must have energy costs and benefits. Harris engages in an extreme form of adaptationism, creating adaptive stories unmediated by any sense of the operational requirements of ecology. This approach hardly represents the sophistication of evolutionary ecology and the multiplicity of ways its theories and methods could be adapted to anthropological use.

The book does not cope with the central theoretical problem in attempts to deal with humans ecologically: how to treat the interaction of economic and energy currencies, since they do not match up in any obvious ways (Bennett 1976, E. Smith I980). Because of culture, human ecosystems are not bounded in space and time in the same way that nonhuman systems are. The kinds and amounts of 
information they process are different. No account is taken of this fact.

Instead Harris tries to make history the arbiter of adaptation, arguing that a certain amount of time is required for a system either to settle adaptively into a stable strategy or to disappear. No means of determining the amount of time needed is ever suggested, or any means of distinguishing between systems that are maladaptive and those that are not yet adapted. These questions require answers from any theory that calls itself scientific.

Harris' view of human history is not nearly so new or revolutionary as he thinks it is. He treats tribal societies as ones where people do what they must in a balanced relationship with the environment, avoiding the temptation to do otherwise by wrapping their actions in fantasy. In early states, people behave pretty much as in tribal societies, but the logic of political power forces a certain degree of environmental modification. In capitalist states, people are driven to deplete the environment by the logic of capitalism, while their consciousness of the situation is the exact opposite of what is really happening. The ideal future society is one in which scientific consciousness of the ecological and economic constraints at the base of all societies will predominate. Through this knowledge a reconciliation of consciousness and reality will be created so that the dichotomy between nature and culture can be abolished. This is a rather commonplace form of utopian rationalism.

Cows, Pigs, Wars, and Witches leaves the following problems unresolved: What causes the major transitions in human history? What is the relationship between consciousness and ecology? What is adaptation? How can we distinguish between systems that are maladaptive and systems that simply have not yet achieved an adaptive balance? What is the source of scientific objectivity? Cannibals and Kings and Cultural Materialism are Harris' attempts to address some of these questions.

\section{Cannibals and Kings}

Cannibals and Kings, subtitled The Origins of Cultures, shows that Harris is aware of the major flaw in Cows, Pigs, Wars, and Witches: 
the lack of a dynamic that moves history through the transitions he has described. This work is intended to provide that dynamic. He states the argument succinctly at the outset:

In the past, irresistible reproductive pressures arising from the lack of safe and effective means of contraception led recurrently to the intensification of production. Such intensification has always led to environmental depletion, which in general results in new systems of production.... [Harris $1977: x \dot{x}]$

Then he brings his policy position forward:

That a blind form of determinism has ruled the past does not mean that it must rule the future.... I have no difficulty in believing both that history is determined and that human beings have the capacity to exercise moral choice and free will.... In my opinion, free will and moral choice have had virtually no significant effect upon the directions taken thus far by evolving systems of social life. ... It behooves those who are concerned about protecting human dignity from the threat of mechanical determinism to join me in pondering the question: why has social life up to now consisted overwhelmingly of predictable rather than unpredictable arrangements? I am convinced that one of the greatest existing obstacles to the exercise of free choice on behalf of achieving the improbable goals of peace, equality, and affluence is the failure to recognize the material evolutionary processes that account for the prevalence of wars, inequality, and poverty. [pp. xi-xii]

Cannibals and Kings provides a population/environment motor to drive the cultural evolutionary process along. The book also clarifies Harris' ethical stance considerably. Equating rationality, knowledge, and the exercise of freedom, he seeks to study the laws of nature in order to defeat them or at least to subordinate them to certain ethical standards.

\section{The Cultural Basis of Cultural Materialism}

Harris' population/environment argument, strangely enough, rests on a cultural foundation, though apparently he does not see it as such. He claims that the severe costs of infanticide to humans are the 
real motor of human history. It is very difficult for humans to endanger pregnant women's lives and to kill children. But he does not explain why the killing of infants is worse for humans than for other animals. Nor does he argue that it is harder on human females physically. Harris believes that infanticide has a high moral and cultural cost.

For this to be the case, Harris has to argue for certain panhuman cultural capacities that have not evolved over time. The high cost of infanticide is treated as a universal, fixed characteristic of the human species as a whole. This generic statement about what is "natural" to humans is undefended and is incompatible with Harris' evocation of an evolutionary view. In such a view, a fixed, universal "human nature" has no place.

"I suspect," Harris writes, "that only a group under severe economic and demographic stress would resort to abortion as its principal method of population regulation.... In the case of both geronticide and infanticide, outright conscious killing is probably the exception" (p. I5). His concept of "costs" of population control is clearly a culturally mediated one, resting on a view of panhuman moral sentiments, an immensely popular idea. Harris is an optimist about human nature, a point relevant to much of his popularity because audiences respond favorably to it.

\section{Adaptationism}

Cannibals and Kings is even looser than the previous work in its appeal to adaptationist stories. Harris states, "Yet I have already shown that what keeps hunter-collectors from switching over to agriculture is not ideas but cost/benefits.... This theory explains why the domestication of plants and animals occurred at the same times and places in the Old World" (pp. 26-27; emphases mine). "I have shown" would be more accurately stated as "I have argued." As for the claim that the theory "explains" the timing of domestication, Harris offers a hypothesis, then takes it as confirmed, and then converts it into a theory that explains. This indefensible strategy is consistently pursued throughout the book.

In discussing the origin of war, Harris argues that variations in the 
intensity of war are caused by cultural factors. "Obviously it is part of human nature to be able to become aggressive and to wage war. But how and when we become aggressive is controlled by our cultures rather than by our genes" (p. 37; emphasis mine). This kind of argument posits a timeless human nature apart from history. It also embodies an extreme form of environmentalism: humans have the capacity to do many things but the particular environment absolutely determines what they will do. Soon Harris takes the next step: "Warfare ... is not the expression of human nature, but a response to reproductive and ecological pressures. Therefore, male supremacy is no more natural than warfare" (p. 57).

Human nature is constant but its expression varies in accordance with the situation. If human nature is constant, then how can Harris have any hope that humanity will change in the future? He must call on science to create an environment that will permit the expression of the "true human nature" (as opposed to the nature of observed humanity). This position is neither new nor defensible according to the cultural-materialist ground rules he lays down. It is familiar to us from Hippocrates and Jean Bodin, among others.

\section{Material Causes, the Human Will, and the}

Ethical Duty of Science

In regard to causal statements, Harris' lack of attention to operational questions places him in an awkward position. He states, for example, "The Oedipus complex was not the cause of war; war was the cause of the Oedipus complex (keeping in mind that war itself was not a first cause but a derivative of the attempt to control ecological and reproductive pressures" (pp. 65-66). Then he justifies this statement with the following: "It is an established principle in the philosophy of science that if one must choose between two theories the theory that explains more variables with the least number of independent unexplained assumptions deserves priority" (p. 66).

This, of course, is true, but he has left out a step. Ockham's razor can be invoked only in operationalized explanations. Since statements such as those about the Oedipus complex are not in any operational form, it is impossible to decide which alternative view does contain 
the largest number of unexplained assumptions. Harris rarely moves to the level of operational research; yet the issues he tries to resolve cannot be dealt with by logical manipulation alone.

Other statements move us toward an even more ambiguous stance on causality:

War and sexism will cease to be practiced when their productive, reproductive, and ecological functions are fulfilled by less costly alternatives. Such alternatives now lie within our grasp for the first time in history. If we fail to make use of them, it will be the fault not of our natures but of our intelligence and will. [P. 66]

Here the separation of will and intelligence from human nature must be kept alive if the dynamic of his model of history is to work. Again we are required to view human nature as outside of history-an enterprise that makes no biological sense. Yet without such a view Harris' moral claims lose much of their support, as in the following case:

I urge those who feel that my explanation of the evolution of culture is too deterministic and too mechanical to consider the possibility that at this very moment we are again passing by slow degrees through a series of "natural, beneficial, and only slightly ... extra-legal" changes which will transform social life in ways that few alive today would consciously wish to inflict upon future generations. Clearly the remedy for that situation cannot lie in the denial of a deterministic component in social processes; rather, it must lie in bringing that component into the arena of popular comprehension. [P. 82]

By bringing these determinisms to the attention of the people, he hopes to improve the situation. Human nature is assumed to be good and reasonable; humans, faced with the right information, are likely to make much more constructive decisions than they have done in the past. As I said, Harris is an optimist.

And then he hedges: "I do not claim that the analysis of ecological costs and benefits can lead to the explanation of every belief and practice of every culture that has ever existed" (p. I37). In the absence of operational definitions, this kind of caveat becomes the ultimate fudge factor. It says that the explanation explains what it explains and does not explain what it does not explain. 
Finally, Harris derives a lesson from Karl Wittfogel:

The effective moment for conscious choice may exist only during the transition from one mode of production to another. After a society has made its commitment to a particular technological ecological strategy for solving the problem of declining efficiency, it may not be possible to do anything about the consequences of an unintelligent choice for a long time to come. [P. I63]

This is quite an important point, for it adds to his earlier model of societies that are adapted and others that are not the idea that there are certain open doors in history. Only during these transitions is free will operative. This is Harris' way of reconciling his cultural materialism with his appeal to free will. It is not clear that the reconciliation makes any sense.

Harris believes that we are at such an open juncture now; thus the exercise of informed free will is crucial at present. He states:

No one who detests the practice of kowtowing and groveling, who values the pursuit of scientific knowledge of culture and society, who values the right to study, discuss, debate, and criticize, or who believes that society is greater than the state can afford to mistake the rise of European and American democracies as the normal product of a march toward freedom. [P. I75]

How, then, do we keep them from disappearing?

Only by decentralizing our basic mode of energy production ... can we restore the ecological and cultural configuration that led to the emergence of political democracy in Europe. This raises the question of how we can consciously select improbable alternatives to probable evolutionary trends.... To change the world in a conscious way one must first have a conscious understanding of what the world is like. ... It is only through an awareness of the determined nature of the past that we can hope to make the future less dependent on unconscious and impersonal forces.... While the course of cultural evolution is never free of systemic influence, some moments are probably more "open" than others. The most open moments, it appears to me, are those at which a mode of production reaches its limits of growth and a new mode of production must soon be adopted. We are rapidly mov- 
ing toward such an opening. ... In life, as in any game whose outcome depends on both luck and skill, the rational response to bad odds is to try harder. [Pp. 194-96]

This idea of the open moment and the appeal to democratic values together provide the drama and the call to action that makes Harris a compelling writer. But it does not make him a materialist or an evolutionist in any clear sense. Indeed, we have heard similar arguments before, in the writings of Jean Bodin and a host of other preevolutionary social reformers.

\section{Cows, Pigs, Wars, and Witches Revisited}

Does Cannibals and Kings correct the weaknesses of Cows, Pigs, Wars, and Witches? It does not. The use of adaptationist arguments is more rampant and attention to operationalism is nil. Even the occasional encouragements to readers to get the data needed to examine these general propositions have pretty well disappeared.

The discussion of the relationship between culture and biology is not moved forward from the position taken in the earlier book, though it is restated in clearer terms in Cannibals and Kings. Human nature is given a definite static quality that it did not have earlier, a quality that eliminates much of the possibility of thinking about humans in evolutionary terms. Harris plainly creates a definitional separation between human nature (which is static), human cultures (which evolve), and human will and intelligence (which, though part of human nature, may or may not be exercised according to principles that Harris never clarifies).

The stages of human history are partly explained by means of Harris' abstract model of population increase, intensification, and depletion. This abstract model is quite interesting. With attention to the variety of operational problems involved and the elaboration of serious research hypotheses, this kind of model could be employed and its usefulness could be assessed. But Harris does not rely on the model as much as he claims. The rampant adaptationism of his mode of argument prevents deployment of the model or even discussion of the problems of deployment. He attempts to settle the matter in favor of the model with appeals to inadequate data from the research of others. 
Though at first glance the model appears to be a materialistic one, it relies on the permanence of the values humans place on human life, especially on the lives of mothers and children. Were it not for these values, nothing would prevent abortion and infanticide from solving the population problem. Thus Harris' argument ultimately rests on assumptions about panhuman moral preferences. While these assumptions may be correct, they must be argued forthrightly as part of his model. In actuality Harris has created an eclectic model of human behavior and history, despite the aspersions he casts upon eclecticism.

Finally, the sources of scientific objectivity, a problem in the first book as well, are not clarified at all. To this problem is added the confusion surrounding the desirability of democracy and rationality as guiding principles of human life. Rather than take a more clearly moral position regarding both democracy and rationality, Harris suggests that democracy arises under particular ecological conditions and that these conditions have to be reproduced if democracy is to be preserved. And he argues not that rationality should be an ethical standard but that rationality is scientific and science gives us control over our environment. Thus rationality can be justified because it is evolutionarily successful.

In both of these arguments Harris moves from "is" to "ought" without being aware that he is doing so. He continues to claim that evolutionary biology can guide us into a rational assessment of our situation, and that once we have made that assessment, we will know exactly how to behave. And if we fail, he says, it will be a failure of the will and intelligence. Thus we shall be to blame for not following our material interests.

\section{Cultural Materialism}

To build a "scientific" basis for this view, Harris then wrote Cultural Materialism (1979). This book attempts an epistemological justification of the cultural-materialist strategy, both in its own right and in comparison with all other major strategies of culture analysis. Though Harris continues to write on the subject, the trajectory leading from The Nature of Cultural Things (1964) to Cultural Material- 
ism forms a remarkably complete corpus containing methodology, history of theory, synchronic and diachronic theory, and epistemological justification. Indeed, the overall coherence of his enterprise is intriguing.

Cultural Materialism is not very successful in accomplishing its aims because it does not effectively address most of the issues the earlier books leave unresolved. Instead it sets out a conventional philosophy of science and then proceeds to heap scorn on non-cultural-materialist approaches to the study of human behavior. Though often entertaining-few writers can match Harris' way with words-these critiques do not advance the cause of materialist or evolutionary analysis in any clear way.

\section{Cultural Materialism as Science}

Harris makes quite acceptable general statements about science. He stresses the openminded comparison of alternative theories and argues that a scientific strategy should be explicit regarding the epistemological character of its basic variables, the relationships between the variables, and the interconnected bodies of theory that are relevant to it. He also stresses parsimony in theory formulation and the continual monitoring of theory through empirical testing. No one could disagree that such an enterprise is laudable and perhaps possible. It does not describe what Harris has done in his previous works.

The sections on cultural materialism proper add nothing to the doctrine that has not already been heard before. Harris stresses the distinction between emic and etic data and the importance of measuring the discrepancy between them. And he argues that "the universal structure of sociocultural systems posited by cultural materialism rests on the biological and psychological constants of human nature, and on the distinction between thought and behavior and emics and etics" (Harris r979:5 $\mathrm{x}$ ).

Harris endeavors to incorporate the concept of infrastructure into his argument both to clarify his position and to incorporate those elements of Marxism that he deems useful. Infrastructure, he says, is the interface between nature and culture, and then he states: "Unlike ideas, patterns for production and reproduction cannot be made to 
appear and disappear by a mere act of the will" (p. 58). Where now is the power of the will (and intelligence) claimed in Cannibals and Kings?

\section{Individual Wills and Historical Trajectories}

When Harris turns to the problem of why the sum of individual biopsychological utilities, calculated on their own, will not yield a predictive theory of cultural evolution, his explanation sounds like a negative model of group selection in which groups are much less rational than individuals.

The more hierarchical the society with respect to sex, age, class, caste, and ethnic criteria, the greater the degree of exploitation of one group by another and the less likely it is that the trajectory of sociocultural evolution can be calculated from the average bio-psychological utility of traits. This leads to many puzzling situations in which it appears that large sectors of a society are acting in ways that diminish their practical well-being instead of enhancing it. [Pp. 6I-62]

\section{Decaying Infrastructures and Cultural}

\section{Mystifications}

This idea is quite important for his model because it is the beginning of an attempt to take account of a problem I stressed earlier. He is trying to explain why tribal societies' adjustments to their circumstances break down as social stratification develops.

Later he claims that decaying infrastructures yield the worst forms of ideological mystifications. "A final ideological product of a decaying infrastructure ... [is] the growing commitment of the social sciences to research strategies whose function it is to mystify sociocultural phenomena by directing attention away from the etic behavioral infrastructural causes" (p. I I3).

Harris has finally diagnosed the cause of the "overdose of intellect" he decried in Cows, Pigs, Wars, and Witches: it is the collapsing infrastructure of capitalist industrial society. This decay is causing our consciousness to stray from the real problems we face. Without expert guidance from intellectuals who study the infrastructure directly, we 


\section{I94 | Complex Continuities}

will not survive. This is why we think about what is not rather than about what is.

Cultural materialism is posed as the answer to this dilemma. How we know when an infrastructure is decaying is not addressed.

\section{Eclecticism and Obscurantism}

Among all analytical approaches, Harris most dislikes what he calls eclecticism. He is particularly vexing on this point since he does not distinguish between eclecticism and confusion. He begins by claiming to have discovered that eclecticism is itself a strategy of analysis and then, by fiat, he says that "eclecticism cannot lead to the production of a corpus of theories satisfying the criteria of parsimony and coherence" (p. 288).

This statement reveals much about Harris. Such a bald assertion can be based only on a metaphysical belief that the world of observation operates according to a few simple, regular laws. This view cannot be derived from the principle of parsimony because that principle calls not for the simplest explanation but for the simplest possible explanation. If there is reason to think that the empirical world operates with a set of heterogeneous causes that may not be usefully reduced to each other-biological and cultural causes for examplethen a parsimonious and coherent explanation would have to be "eclectic" in Harris' terms.

He argues that eclecticism would be viable only if nature were fragmented and inconsistent (p. 290), makes undefended metaphysical distinctions between crucial and less important variables (p. 295), and finally equates eclecticism with confusion:

The notion that all the parts of sociocultural systems are equally determinative of each other is a prescription for theoretical chaos. ... There is as little room in the social sciences for the idea that all parts of sociocultural organisms "inneract" [sic] equally, as there is room in physiology for the belief that all parts of a plant or animal are equally vital for the maintenance of life functions. [P. 3 [2]

This is a red herring. An eclectic argument in no way must assert that all parts of a system are equally determinative; rather eclectic 
explanations emphasize that different causes are determinative in different degrees under specifiable conditions. Since Harris' own model includes demographic variables, panhuman nature and ethics, and intelligence and will, it seems to me that he is thinking eclectically himself. Harris does himself a disservice by deemphasizing precisely this eclectic component of his own vision.

Harris' criticism of Marshall Sahlins' rejoinder to his analysis of Aztec cannibalism (Sahlins I978) shows just how pointless this kind of debate can be. According to Harris, Sahlins "has no alternative explanation. The sole purpose of his unremittingly negative critique is to prove that Aztec 'culture is meaningful in its own right,' a proposition to which one cannot object but which has no bearing on the question of whether or not Aztec cannibalism can be explained by cultural materialist theories" (p. 339).

Harris objects to Sahlins' departure from cultural materialism-by which Harris here means demographic/ecological causalities from which other cultural phenomena are derived. Yet Harris' cultural materialism contains a variety of heterogeneous and untestable assumptions about panhuman ethics and morality which drive his whole model. There is nothing less empirically testable or more eclectic in Sahlins' assertion about culture than in Harris' assertions about human nature and values. If cultural systems are meaningful in their own right, and we agree that such systems arise historically and maintain a certain coherence over time, then we can study them systematically and historically in conjunction with the infrastructure without creating any contradictions. The issue between Harris and Sahlins is not science but metaphysics.

\section{America Now}

Harris' more recent book, America Now: The Anthropology of a Changing Culture (I98I), claims to extend his techniques directly to the study of American society. It begins by invoking the collapse of the American dream: "This is a book about cults, crime, shoddy goods, and the shrinking dollar. It's about porno parlors, and sex shops, and 


\section{I96 | Complex Continuities}

men kissing in the streets. It's about daughters shacking up, women on the rampage, marriages postponed, divorces on the rise, and no one having kids ..." (p. 7). Harris is characteristically interesting and entertaining, offering some insightful observations about American life. But there is no connection between his analysis and any applications of energy-flow analysis. The political and moral values that motivate Harris are more clearly in evidence here than ever before.

Harris claims that "traditional moral and spiritual values have lost their appeal"; it is the function of the book to explain why. According to Harris, it is best to start analyzing such problems from the bottom up, "from the changes in the way people conduct the practical and mundane affairs of their everyday lives" (p. II). But rather than relying on a strong form of techno-environmental determinism, Harris hedges by stating that "there is no single chain of causes and effects that can be followed out link by link from one basic change to all others" (p. I2). He sets out to show instead that the whole array of changes fits together in an intelligible pattern; other thinkers, he says, see these problems as unconnected or as the workings of obscure forces. "The task of this book," he writes, "is to reassert the primacy of rational endeavor and objective knowledge in the struggle to save and renew the American dream" (p. I 5). The use of rationality to revitalize democracy, a theme lurking in most of his other works, now takes pride of place.

Throughout he takes up issues that all social commentators on the American scene have examined: shoddy goods, poor service, economic problems, the women's movement, gay liberation, crime in the streets, new religious cults. The subjects are interesting and Harris is good at picking out striking details. Yet even the best of the chapters reads like an analysis in the editorial pages of the New York Times rather than an application of a "science of culture." Nothing in this supposed application of cultural materialism seems to produce insights different from those to be found in standard liberal, conservative, and Marxist critiques. Certainly the connection between this analysis and ecosystems analysis has been severed; in its place stands an invocation of mundane conditions and general patterns of change.

In the end Harris' politics and moral aims dominate all other motives: 
Given the enormous power and formidable inertia of the hyper-industrial oligopolies and bureaucracies, there is only a slim chance of achieving a future more in accord with the vision of freedom and affluence on which past generations of Americans were nourished. Nonetheless, this chance is sufficient to support a rational hope of reversing the trends that have led to America's present malaise. The will to resist and to try for something better is an important component in the struggle against oligopoly and bureaucracy. Of course, to desire something strongly enough to fight for it does not guarantee success. But it changes the odds. The renewal of the American dream may be improbable, but it will become finally impossible only when the last dreamer gives up trying to make it come true. [P. 183 ]

The preservation of America (not unlike the preservation of our species for Wilson) through rationality is the goal. Harris clearly claims that dreamers can affect events, a view that lurks in all of his works under the mantle of ecologism.

Harris equates utopia with a state in which rationality is used in the service of democracy. It is a society in which everything works, people are supportive of one another, the economy is in balance, family structure is stable, the crime rate is low, and irrational religious sects are on the wane. Somehow his long intellectual detour through evolutionary biology and the science of culture has ended up reproducing a conventional middle-class version of American life as the ideal.

\section{Conclusions}

Major metaphysical assumptions are necessary for the operation of Harris' model. He asserts that reality is orderly, causally uniform, and divided directly into the following dichotomous properties:

\begin{tabular}{ll} 
Nature & \multicolumn{1}{c}{ Culture } \\
law & will \\
etic & emic \\
genetic & cultural \\
natural & artificial \\
mundane & transcendent
\end{tabular}


For Harris, human nature is constant and uniform over time and space. Humans have the capacity to discover directly the order that causes reality to operate as it does. Equating science with objectivity about reality, he argues that science demands that cultural systems be derived logically from natural systems.

Harris divides evolution into biological and cultural evolution, yet nothing in his theory provides a basis for such a distinction. He unproblematically considers biological evolution to be an optimizing process and treats selection as a constant force. His implicit ethical stance is democratic, with a sub rosa requirement that democracies be guided by scientist/kings - presumably well versed in cultural materialism.

Finally, he argues that natural causes account for culture as a general human characteristic and for the details of cultural systems. Human history begins in a Malthusian balance but larger stratified societies develop internal contradictions that can be dealt with only through policy. Our failure to understand this predicament is caused by our decaying capitalist infrastructure.

Since Harris' claim to science is based on his evocation of evolutionary biology, and specifically of energy and demographic analysis taken from ecology, it is legitimate to ask how well he has represented these theories in his work. The answer is not well at all. The metaphysical assumptions of evolutionary biology do insist that nature is orderly and subject to the constant action of uniform causes, but there is no evolutionary biological distinction between the material and spiritual aspects of human behavior. This is Harris' addition.

Evolutionary biologists who treat these issues carefully would claim that while it must ultimately be possible to reduce culture to nature, reduction and explanation are not the same thing (Hull I974). The reduction of culture to nature cannot explain the operation of cultural systems-it only sets broad parameters within which culture exists. Further, most evolutionary biologists would certainly agree that there is no acceptable experimental evidence that could lead to the formulation of any general propositions about "human nature."

There is no basis in evolutionary theory for separating biological and cultural evolution. The concept of cultural evolution is a misleading analogy based on a misunderstanding of biological evolution 
(Greenwood and Stini 1977). There is one evolutionary processbiological evolution, of which culture is a part. Nor is evolution an optimizing process (Gould and Lewontin 1979). Selection is neither constant nor unitary; it is episodic and focused on certain traits and certain moments (Gould and Eldredge I977). Finally, most evolutionists feel that evolution does not provide any clear source of ethics. Little of Harris' theory is directly implied in evolutionary biology; most of what he says runs counter to the core of biological science. He did not need evolutionary biology at all for the formulation of his cultural materialism.

The source of Harris' theory is found in pre-evolutionary thought, in which a radical dichotomy between nature and culture was held to be scientifically meaningful and politically useful. The relationship between nature and culture was seen as one of struggle between natural laws and human will, and theorists used naturalistic arguments to set ethical and political standards. Harris' appeal to rationality, will, and intelligence belongs to this tradition, not to the tradition of Darwin.

To understand Harris' views, a knowledge of the works of Hippocrates, Bodin, and Torres Villarroel is more helpful than a reading of Darwin. The conflict between the genealogical and environmental principles and the political management of states is a key theme for Harris. With Torres he shares the basic underlying notion that a series of fundamental and stable moral premises undergird "human nature" and that our relationship with nature can either support or destroy these premises. Torres' desire to have people recognize their basic constitutions and to harmonize themselves with "nature" is virtually identical to Harris' plea for a rational approach to the problems of population, pollution, and war. Torres' scathing critique of abstract intellectualism is closely echoed in Harris' commentaries on contemporary social scientists, humanists, and politicians. All these thinkers find sermons in nature in ways that should make evolutionary biologists shudder. 